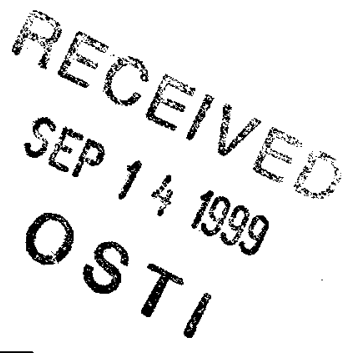

Energy R\&D in the Netherlands

\author{
E.E.M. Luiten \& K. Blok
}

Department of Science, Technology and Society

Utrecht University

\title{
April 1999
}

Prepared for

U.S. Department of Energy

under Contract DE-AC06-76RLO 1830

Pacific Northwest National Laboratory

Operated for the U.S. Department of Energy

by Battelle Memorial Institute 


\title{
DISCLAIMER
}

This report was prepared as an account of work sponsored by an agency of the United States Government. Neither the United States Government nor any agency thereof, nor Battelle Memorial Institute, nor any of their employees, makes any warranty, express or implied, or assumes any legal liability or responsibility for the accuracy, completeness, or usefulness of any information, apparatus, product, or process disclosed, or represents that its use would not infringe privately owned rights Reference herein to any specific commercial product, process, or service by trade name, trademark, manufacturer, or otherwise does not necessarily constitute or imply its endorsement, recommendation, or favoring by the United Statēs Government or any agency thereof, or Battelle Memorial Institute. The views and opinions of authors expressed herein do not necessarily state or reflect those of the United States Government or any agency thereof.

\author{
PACIFIC NORTHWEST NATIONAL LABORATORY \\ operated by \\ BATTELLE MEMORIAL INSTITUTE \\ for the \\ UNITED STATES DEPARTMENT OF ENERGY \\ under Contract DE-AC06-76RLO 1830
}




\section{DISCLAIMER}

Portions of this document may be illegible in electronic image products. Images are produced from the best available original document. 
ASTRACT: This report documents trends in R\&D and in particular (public) energy R\&D in the Netherlands. Besides quantitative information on $R \& D$ and energy $R \& D$, the report gives an impression of changes in science and technology policy, energy policy and changes in energy research priorities (both organizational and financial).

In the Netherlands, $2.09 \%$ of GDP (or $\$ 6.7$ billion) was invested in R\&D activities in 1995 . The private sector financed $46 \%$ of all R\&D in that year. A small but significant fraction $(9.3 \%)$ of the research performed in the Netherlands is financed by foreign public and private sector entities.

Energy $R \& D$ has been identified by the national Strategic Foresight Activity as an important area of R\&D for government support in the future. This is due in part to the overall decline in public support for energy R\&D that occurred from 1985 to 1995 . However, recent concern over climate change and energy policy has resulted in increased budgets for energy R\&D. Recent policy documents (e.g., the Memorandum on Energy R\&D in April 1998) and initiatives (e.g., a recent university energy R\&D program; intensification of climate policy, partly in $R \& D$ ) indicate the growing interest in addressing the issue of climate change partly through energy $R \& D$. The Dutch government believes that the liberalization of the energy market in the Netherlands justifies an active role for the government to guarantee the longer-term transformation to a sustainable energy system.

In terms of climate policy, the expanded and more efficient use of natural gas is seen as a suitable transition option towards a sustainable energy system. However, energy efficiency (and in particular energy efficiency in the industrial sector) and the introduction of renewable technologies (solar energy, wind energy and biomass) are generally favored for the long term. Recently, additional funding was allocated for research on industrial "breakthrough" technologies, photovoltaic energy, and biomass research.

Best available data suggest that the private sector's energy $R \& D$ investments are on par with and quite close to the level of the government's energy R\&D budgets. Renewable energy R\&D, nuclear fission and fusion are predominantly financed by the public sector. However, energy efficiency receives the largest share of the total governmental energy RD\&D budget (about 40\%). The majority of the private sector's energy R\&D investments are devoted to energy efficiency. Private sector investments also exceed those of the government in the area of power storage technologies.

KEY WORDS: Energy R\&D, the Netherlands, climate change 


\section{The Netherlands}

1997 Population: $15,567,100$ (CBS, 1998)

1996 GDP: $\$ 316.9$ billion $^{1}$ (fl 659.3 million)

(CBS, 1998)

1995 National R\&D Effort (Tijssen et al., 1998; CBS, 1997)

- $\$ 6,371$ million (fl 13,252 million)

- $\quad$ R\&D as percentage of GDP: $2.09 \%$

Percentage performed by:

- Universities: $28.8 \%$

- Semi-public research institutes 2 : $19.1 \%$

- Private sector: $52.2 \%$

Percentage financed by:3

- Government: $42.2 \%$

- Private: $46.1 \%$

1996 National Energy R\&D Effort: (Strker and de Jager, April 1998)

- $\$ 262$ million (fl 543 million) total for public sector, private sector and the European Union

- \$131 million (fl 272 million); governmental energy research, development, and demonstration (RD\&D) expenditure

Energy RD\&D accounts for approximately $4 \%$ of all (public and private sector) RD\&D performed in the Netherlands

\section{Chapter Overview}

Summary of Analytical Findings

National Science and Technology Effort

National Energy Policy

Energy Technology Trends

Energy R\&D Program Descriptions

\footnotetext{
${ }^{1}$ All figures shown are based on purchasing power parity calculations made using currency deflators published by the Organization for Economic Cooperation and Development (OECD). See OECD, Statistics Directorate, National Accounts 1960-1996: Main Aggregates Volume 1 (Paris: OECD, 1998).

${ }^{2}$ For the purpose of this report, semi-public rresearch institutes are defined as the group of Dutch institutes, whose primary purpose is the performance of $R \& D$ (CBS, September 1997). The dollar value of the $R \& D$ performed by these institutions is computed by subtracting from the national $R \& D$ expenditure the private sector's $R \& D$ effort and the R\&D performed at universities. This collection of research institutes is rather broad. For example, it includes the five Dutch Large Technological Institutes: Netherlands Energy Research Foundation (ECN), Delft Hydraulics (WL), Delft Geotechnics (GD), the National Aerospace Laboratory (NLR), and the Maritime Research Institute Netherlands (MARIN). Also included are the Netherlands Organisation for Applied Scientific Research (TNO), the Netherlands Organisation for Agricultural Research (DLO), and research institutes associated with the Netherlands Organisation of Scientific Research (NWO). Lastly, some private nonprofit research institutes are also included in this category. The majority (66\%) of the research performed by semi-public research institutes is applied research (CBS, September 1997).

${ }^{3}$ In $1995,9.3 \%$ of the national R\&D effort was financed by foreign money (Tijsen et al., 1998).
} 


\section{SUMMARY OF ANALYTICAL FINDINGS}

Total national (public and private sector) Dutch R\&D investments stood at $\$ 6.4$ billion in 1995 . R\&D as percentage of GDP peaked in 1988 and declined until 1993. Since 1993, national R\&D investments have recovered slightly. Changes in the private sector's support for $R \& D$ are largely responsible for these fluctuations in the overall national pattern of R\&D spending. In particular, reductions in the level of support for R\&D provided by five large Dutch-based multinational firms was principally responsible for the downturn in the late 1980s and early 1990s. Since 1993, the recovery in private sector investment in $\mathrm{R} \& D$ is largely attributable to a growing number of technology-intensive medium-sized firms.

Although government support for $R \& D$ has gradually increased over the last decade, there have been some significant changes in the composition of government-funded research. For example, the government's strong support for industrial productivity and industrial technology R\&D programs in the 1980 s has largely disappeared in the later half of the 1990s. Support for agricultural R\&D and energy $\mathrm{R} \& \mathrm{D}$ has also decreased over this time period. The largest increases over this period were for general science programs.

A significant fraction (47.9\% in 1995) of Dutch national R\&D is performed in "semi-public research institutes" and universities. The public R\&D performers - universities and semi-public research institutes - are increasingly being urged to lessen their dependence on direct government subsidies for performing $R \& D$ and to finance their $R \& D$ efforts through avenues such as contracts with the private sector and merit-based grants from the public sector. In doing this, the government is attempting to create a more "market-oriented" research infrastructure (i.e., a situation that is better able to match supply and demand for research). Another goal is to promote higher quality research.

These attempts are in line with a change in policy vision. A better exploitation of R\&D results should be achieved by cooperation and fine-tuning between actors involved. Budget pressures and a desire to fund the highest leverage R\&D have also led to a growing interest in and use of "foresight studies" by the Dutch government. Through these activities the government is seeking to learn what areas of research are strategically important for the future of the Netherlands and how to get the most out of the research infrastructure by seeking to identify and fund the best university research schools and scientists. Energy $\mathrm{R} \& D$ has been identified as one of the priority areas for future government support by the foresight studies.

The current major themes of Dutch energy policy are liberalizing the energy market and stimulating development and adoption of energy efficient technologies and renewable energy systems as a way to address climate change.

Energy efficiency policy in the Netherlands is increasingly becoming more active. The government announced that - in addition to further Voluntary Agreements - it might rely more heavily on promulgating and adopting performance standards and regulations, where necessary. These more active, forcing measures are supporting the government's policy focus, which is based on reliance on selfregulation and voluntary agreements.

The Dutch government believes that it is still too early to say precisely what the effect of energy market liberalization (e.g., utility deregulation) will be on the many voluntary agreements in place with the energy sector to promote energy efficiency and private investments in energy R\&D. The energy sector's willingness to invest in long term R\&D is expected to decrease because of mounting pressures for energy 
R\&D to produce short-term results. In an effort to address this possible shortfall in private sector energy $R \& D$, the government has included incentives for the further promotion of energy efficiency and the deployment of renewable energy technologies in the new Electricity and Gas Acts. There appears to be a consensus in the Netherlands that the government has a role to play (in consultation with the private energy sector) in guaranteeing an adequate long-term energy $R \& D$ effort needed to shift towards a "sustainable energy system." Focus is on solar energy, wind energy, energy from biomass, energy efficiency improvement and an optimized application of natural gas.

Historically, reducing the Netherlands' dependency on oil imports and environmental considerations arising from energy use were the principal drivers of the government's investments in energy conservation R\&D and energy R\&D designed to further develop domestic energy sources (mainly wind energy, solar energy, and waste/biomass energy). More recently, environmental drivers, especially climate change, lie behind the government's support for energy efficiency R\&D and renewable energy R\&D.

In the public sector, the overall energy R\&D budget declined from 1990 to 1995 . However, recent concern over climate change and energy policy has resulted in increased budgets for energy R\&D (especially renewable energy $\mathrm{R} \& D$ ) and other ways to reduce $\mathrm{CO}_{2}$ emissions. The government intends to increasingly involve private parties such as the private sector natural gas and electric utilities in its efforts to prioritize publicly funded energy R\&D. The purpose of this is to strive for better coordination across the public and private "energy knowledge infrastructures." Also by better matching "supply and demand" for energy R\&D, the government hopes to affect a more efficient allocation of public resources for energy R\&D.

The budget for coal R\&D has experienced the largest decreases of energy technology area over the past decade. Support for nuclear energy R\&D has decreased dramatically, although the Dutch government has decided to continue supporting some nuclear energy research so that it can be assured of having the capacity to carry out nuclear energy $R \& D$ if the need should arise in the future. In keeping with the energy policy trends discussed above, government support for renewable energy R\&D and energy efficiency R\&D has been on the rise for most of the past decade. Recently, the government has begun to provide support for new fuels such as hydrogen, bio-gasses and bio-fuels, electricity technology (grid optimization and storage), and carbon management technologies.

The largest share of government energy $R \& D$ (and public energy $R \& D$ ) is devoted to industrial energy efficiency programs. These programs (along with building energy efficiency programs) appear to be more project-oriented and applied, given that they tend to focus on deploying innovative technologies. Only rather modest sums are allocated to support the long-term development of these technologies (e.g., heat pumps and membranes). The continuing focus on improving industrial energy efficiency will likely necessitate a shift in the types of technologies being developed from R\&D centered on optimizing current production facilities towards R\&D focused on the improvement of core process technologies.

The private sector concentrates its energy R\&D in the areas of oil and gas, energy conservation, and power and storage. There appears to be significant cooperation between (and amongst) private companies and the semi-public research infrastructure in the field of energy R\&D. 


\section{NATIONAL SCIENCE AND TECHNOLOGY EFFORT}

In 1995, the Dutch national R\&D effort reached $\$ 6,371$ million (F1 13,352 million). Private sector firms and private for-profit laboratories performed \$3,296 million in R\&D in 1995 (Fl 6,855 million). Semipublic $^{4}$ research performers accounted for an additional $\$ 1,301$ million of the R\&D performed that year (F1 2,707 million), while universities accounted for $\$ 1,774$ million of R\&D performance (F1 3,689 million) (CBS, September 1997).

Figure 1 shows trends in the performance of $R \& D$ in the Netherlands $R \& D$ over the past 25 years.

Growth in national R\&D expenditures slowed significantly at the start of the 1990s. When corrected for inflation, the growth in R\&D expenditures was $1.5 \%$ per year from 1990 to 1995 . From 1985 to 1990 , growth was $2.71 \%$ per year (Tijssen et al., 1998). Over the past decade, the contribution of the different sub-sectors (private $R \& D$, university $R \& D$, and semi-public $R \& D$ ) to national $R \& D$ performance has remained relatively stable $(52 \%, 29 \%$, and $19 \%$ respectively) (see also Figure 2 ).

Figure 1: Total National R\&D in the Netherlands: by Performing Sector 5

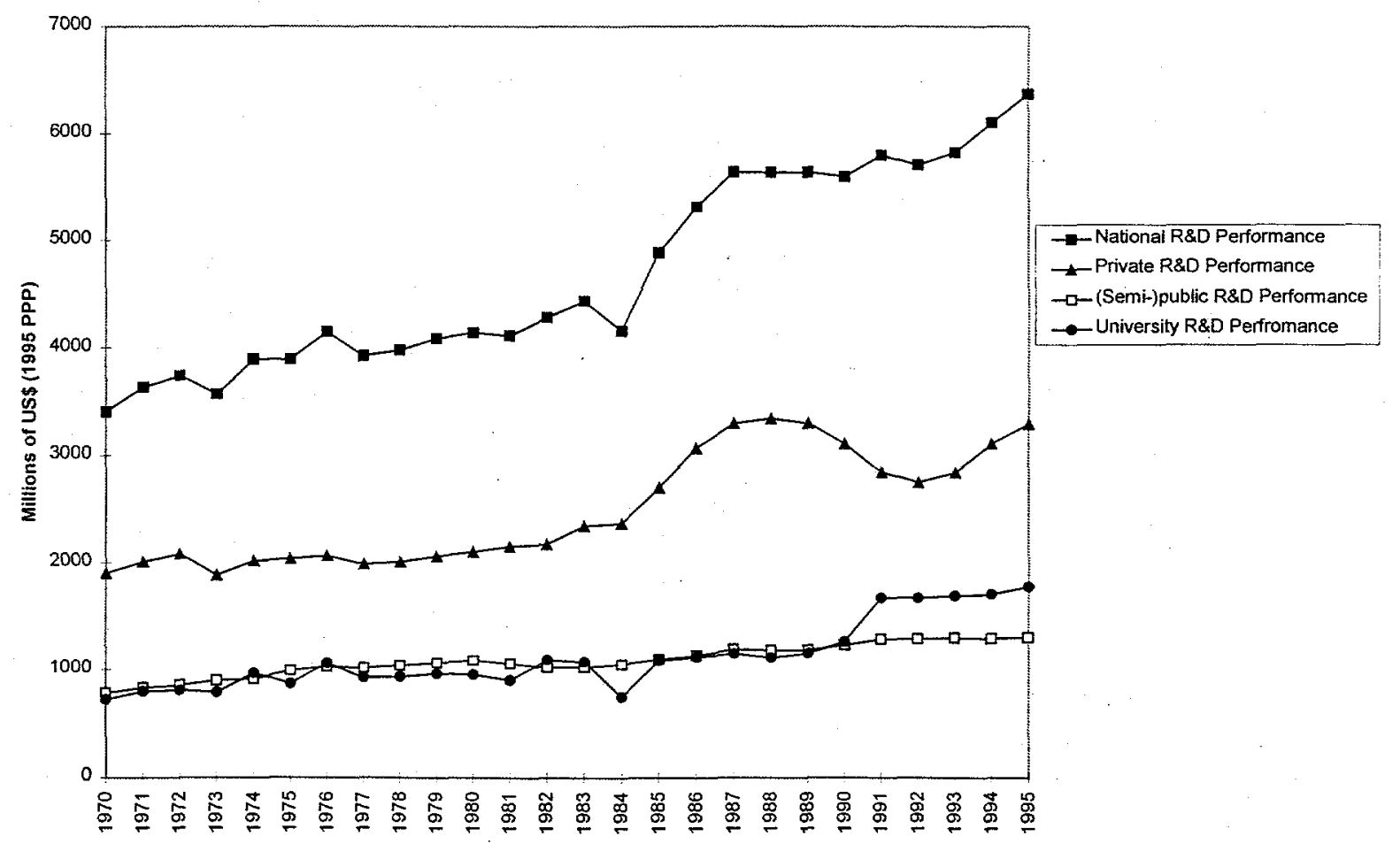

In $1985,48 \%$ of the national R\&D expenditure was financed by the government; however, by 1995 the government's share had fallen to $42 \%$. The private sector's share in national R\&D financing decreased over this same time period from $49 \%$ to $46 \%$.

"Please see footnote 2 for the definition of "semi-public R\&D performers."

${ }^{5}$ There have been two major revisions to this data set in recent years. Beginning in 1993 companies with fewer than 50 employees were included in the "private R\&D performance" category. This had the effect of slightly increasing the figures for private $R \& D$ performance. The second revision concerns the method by which "university R\&D performance" was calculated. This revision resulted in a significantly higher estimate $30 \%$ or about $\$ 350,000$ between 1990 and 1991) for university R\&D performance. Source: CBS, various yearly reports. 
An important explanation for the decreasing contribution of both government and private companies is the increase in resources coming from abroad. Between 1990 and 1995, R\&D performed in the Netherlands that was financed by a foreign source increased almost fivefold. One significant manifestation of this increasing internationalization is the Netherlands' growing participation in R\&D programs sponsored by the European Union (Tijssen et al., 1998; CBS, September 1997).

Figure 2 shows R\&D as a percent of GDP for the various $R \& D$ performing sectors in the Netherlands. After a decrease between 1988 and 1992, national R\&D intensity has recovered. The national R\&D intensity in 1995 was $2.09 \%$ of GDP. Figure 2 clearly shows that changes in private R\&D effort are the most important reason for fluctuations in the total R\&D effort.

\section{Trends in Private R\&D}

The significant decrease in private $R \& D$ performance that occurred in the late 1980 s and early 1990 s is mainly explained by the decline in R\&D activities of five major Dutch R\&D-intensive multinational companies. 6 These reductions in R\&D spending were particularly large for the Netherlands's largest R\&D spender, Philips, which implemented a series of significant budget cuts when it was confronted with a deteriorating market position in 1987. The relative role of these five large firms in supporting private sector R\&D is decreasing. In 1985 these five firms performed $60 \%$ of private sector R\&D activity; by 1995 their share decreased to $46 \%$.

While these five large firms have decreased their support for R\&D in the Dutch economy, smaller firms have increased their relative role in supporting R\&D. Between 1990 and 1995, small and medium-sized enterprises (defined as having between 50 and 200 employees) increased their share of private R\&D performance from $7.8 \%$ to $13.7 \%$ (CBS, September 1997). The number of start-up technology-based companies has grown throughout the 1990s (CBS, October 1996). Even though these data demonstrate that the Dutch economy's performance of R\&D is becoming less tied to the fortunes of the "big 5 firms," $70 \%$ of the total private $R \& D$ effort is still performed by companies with more than 1,000 employees.

Private $R \& D$ performance was $1.09 \%$ of GDP in 1995 (private $R \& D$ intensity; see Figure 2). The share of private expenditures in the country's R\&D intensity is relatively small when compared with other countries. One explanation for the relatively small private contribution to national R\&D intensity is the structure of the Dutch economy. Less R\&D-intensive sectors such as services, agriculture, and food and beverages account for a significant share of the Dutch economy.

When comparing investments in $R \& D$ (an input measure) and patent activity of the Netherlands (an output measure), the Netherlands score relatively high when compared with other countries. The main areas of patenting activity are farming equipment, agricultural and food technology, audio-visual technologies, basic chemistry, biotechnology, and electro-technologies (CBS, October 1996). The paradox of modest $R \& D$ intensity and relatively high patent output can be explained partly by the patent activity of large Dutch multinational companies, which also perform $R \& D$ in other countries but file the resulting patents in the Netherlands. These large firms account for $30-35 \%$ of the patents in the Netherlands (CBS, September 1997).

\footnotetext{
${ }^{6}$ Akzo Nobel (chemical; healthcare products, coatings, chemicals and fibers), DSM (activities in life science products, performance materials, polymers and industrial (fine) chemicals), Philips (consumer electronics), Royal Dutch/Shell (oil and natural gas firm), and Unilever (food/ consumer products).
} 
Figure 2: Netherlands R\&D Performance as Percent of GDP (Tijssen et al., 1998)

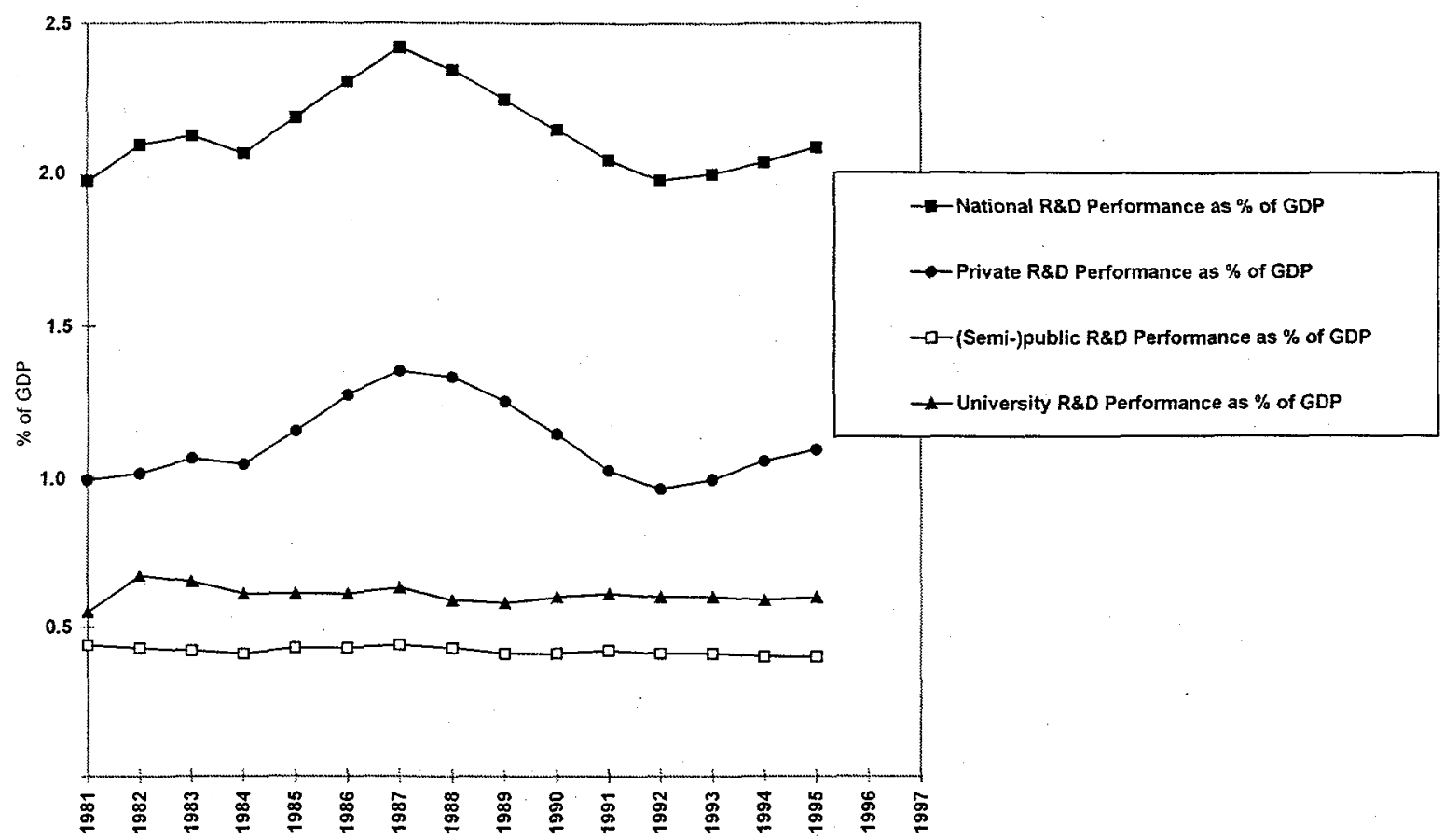

Trends in Public R\&D

Total public sector support for all forms of R\&D in 1995 was $\$ 2,772$ million dollars ( $F 15,766$ million) (CBS, September 1997). From 1985-1996, public sector support for R\&D has increased by $2.8 \%$ percent in real terms. However, the Dutch economy grew at faster pace $(4.1 \%)$ over that period, and therefore government-supported R\&D funding as a percentage of GDP has been steadily eroding. In 1985, government R\&D accounted for $0.92 \%$ of GDP, but it had decreased to $0.77 \%$ by 1997 (Tijssen et al., 1998; Ministry of Education, various yearly reports).

The government's contribution to privately performed R\&D has been on the decline for more than a decade. In 1985, the government financed $13 \%$ of the research performed in the private sector, while in 1995 it supported only about 7\% of the private sector's total effort (Tijssen et al., 1998).

Because of the decreasing role of the government in financing $R \& D$, both universities and the semipublic research institutes have been forced to acquire research funding from other sources. For the semipublic research institutes, the majority of whose efforts are in applied research, this reduction in funds from the national government has resulted in heightened efforts to attract funds from the private sector (CBS, September 1997 and Tijssen et al., 1998). Semi-public research institutes received $16 \%$ of their funding from private companies in 1995, up from only $12 \%$ in 1990 (CBS, September 1997).

In 1995, the Ministry of Education, Culture, and Sciences contributed $62 \%$ of the governmental budget available for financing $R \& D$, while the Ministry of Economic Affairs accounted for the second largest share of $16 \%$. The dominant role of the Ministry of Education, Culture, and Sciences stems from its mission to finance universities directly. Its support constitutes the "primary flow" of funds to universities, accounting for about $42 \%$ of the government's R\&D budget. This Ministry also funds the 
Netherlands Organization for Scientific Research (NWO), ${ }^{7}$ which channels resources to its own research institutes, to Dutch universities, and to the semi-public research institutes.

The remainder of the Netherlands's governmental budget to finance R\&D comes from the Ministry of Agriculture, Nature Management and Fisheries (7\%); the Ministry of Transport, Public Works and Water Management (4\%); the Ministry of Housing, Spatial Planning and Environment (3\%); and the Ministry of Defence (3\%) (Ministry of Education, Culture, and Sciences, various yearly reports).

Priority changes in governmental R\&D support are reflected in data from the science budgets of the Ministry of Education, Culture and Sciences (see Figure 3, 4, and 5). Besides university R\&D financing, 12 categories of $R \& D$ areas are distinguished (see Figure 3). Energy $R \& D$ is one of them.

\section{Figure 3: The Netherlands' Government Support for R\&D Financing8}

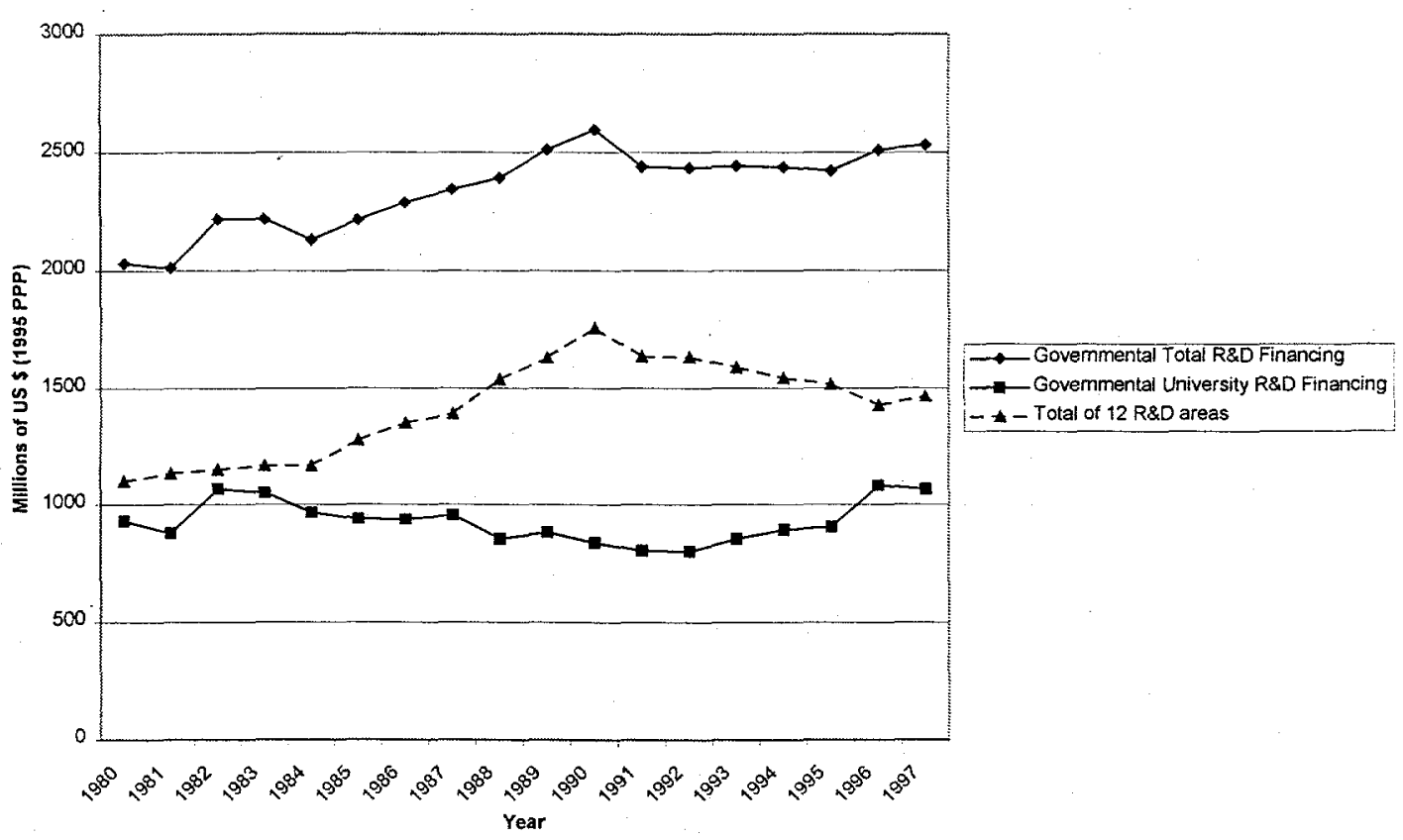

Growth in R\&D for the 12 major socioeconomic areas was about $30 \%$ from 1980 to $1996 / 97$. Among the 12 R\&D areas funded by the federal government, the largest increases over the past decade have occurred in the areas of industrial productivity and technology and non-university basic research (see Figures 4 and

\footnotetext{
${ }^{7}$ NWO (The Hague) is an agency of the ministry of Education, Culture and Sciences. NWO stimulates, initiates and coordinates top-level scientific research, which is mainly carried out in Dutch universities and national research institutes. NWO manages resources from the government ( $\$ 300$ million in 1997; "second flow" of resources to universities). It is an intermediary organisation. Assessment and evaluation of research proposals by independent experts, a so-called peer-review system, is the basic mechanism through which NWO allocates its resources and tries to ensure the quality of research. Over two-thirds of NWO expenditures benefit academic research. NWO is responsible for about $17 \%$ of national academic research capacity.

${ }^{8}$ The Science Budgets give an indication of the (estimated) governmental budget available to finance R\&D (see Ministry of Education, Culture and Sciences, various yearly reports). Unfortunately, these budgets are not reported each year in the same format. Consequently, data for some years are missing. The most reliable historical data available are used in these figures. In 1996, the method used in calculating university R\&D changed inducing an increase in this category. All data used in Figures 6 and 7 are taken from (Ministry of Education, Culture, and Sciences, various yearly reports).
} 
5). The non-allocated $R \& D$ area grew also considerably (from $\$ 60$ million to $\$ 125$ million). Nonuniversity basic research has also grown considerably over this time period. Funding in this area increased from roughly $\$ 190$ million in 1980 to $\$ 300$ million in $1996 / 7$, a real increase of $30 \%$. The increases in funding for NWO and the Royal Netherlands Academy of Arts and Sciences (KNAW) ${ }^{9}$ indicate the growing importance of non-university performers of basic research (Ministry of Education, Culture, and Sciences, 1997).

Large fluctuations occurred in industrial productivity and technology R\&D. In the mid-1980s, the government began a broad initiative to stimulate industrial competitiveness and innovation (e.g., the INSTIR instrument, Innovation Oriented Research Programmes). Funding grew from $\$ 150$ million in 1980 to around $\$ 500$ million in $1989 / 90$. Most of this industrial productivity and technology $R \& D$ is supported by the Ministry of Economic Affairs (Ministry of Education, Culture, and Sciences, 1988). However, industrial productivity and technology R\&D spending declined rapidly after 1990 to around $\$ 300$ million per year currently.

Figure 4: Government Support for 12 R\&D Socioeconomic Objectives

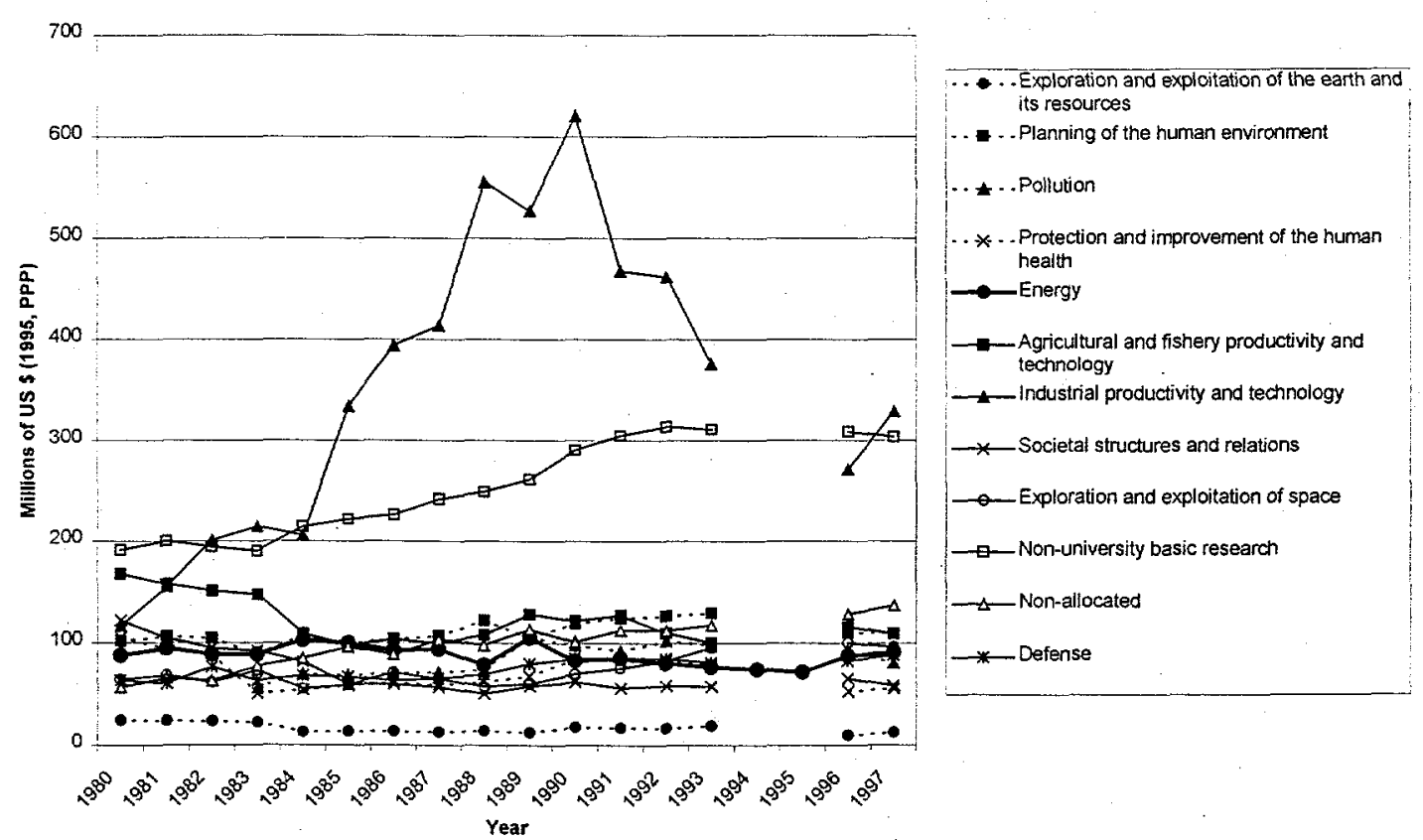

Funding devoted to Defense and Exploration of Space grew also (from $\$ 60$ million each in the early 1980 s to respectively $\$ 85$ and $\$ 100$ million now). Investments in pollution R\&D increased significantly from 1985 to the early 1990 s (from $\$ 60$ to $\$ 100$ million), apparently stagnating (currently around $\$ 90$ million).

The largest decreases in support occurred in the area of societal structures and relations R\&D; from 1980 to 1985 funding decreased $\$ 50$ million per year. Since then it has fluctuated around $\$ 60$ million. Other decreases have occurred in $R \& D$ investments in exploration of the earth, human health, and agricultural productivity and technology.

\footnotetext{
${ }^{9}$ The KNAW (Amsterdam) is an umbrella organisation for basic scientific research institutions and information dissemination agencies. The main tasks of the Academy are advising the government on science, stimulating (international) co-operation between scientific researchers, implementing government programmes and projects), and peer review.
} 
Figure 5: Government Support for 10 (of 12) R\&D Socioeconomic Objectives

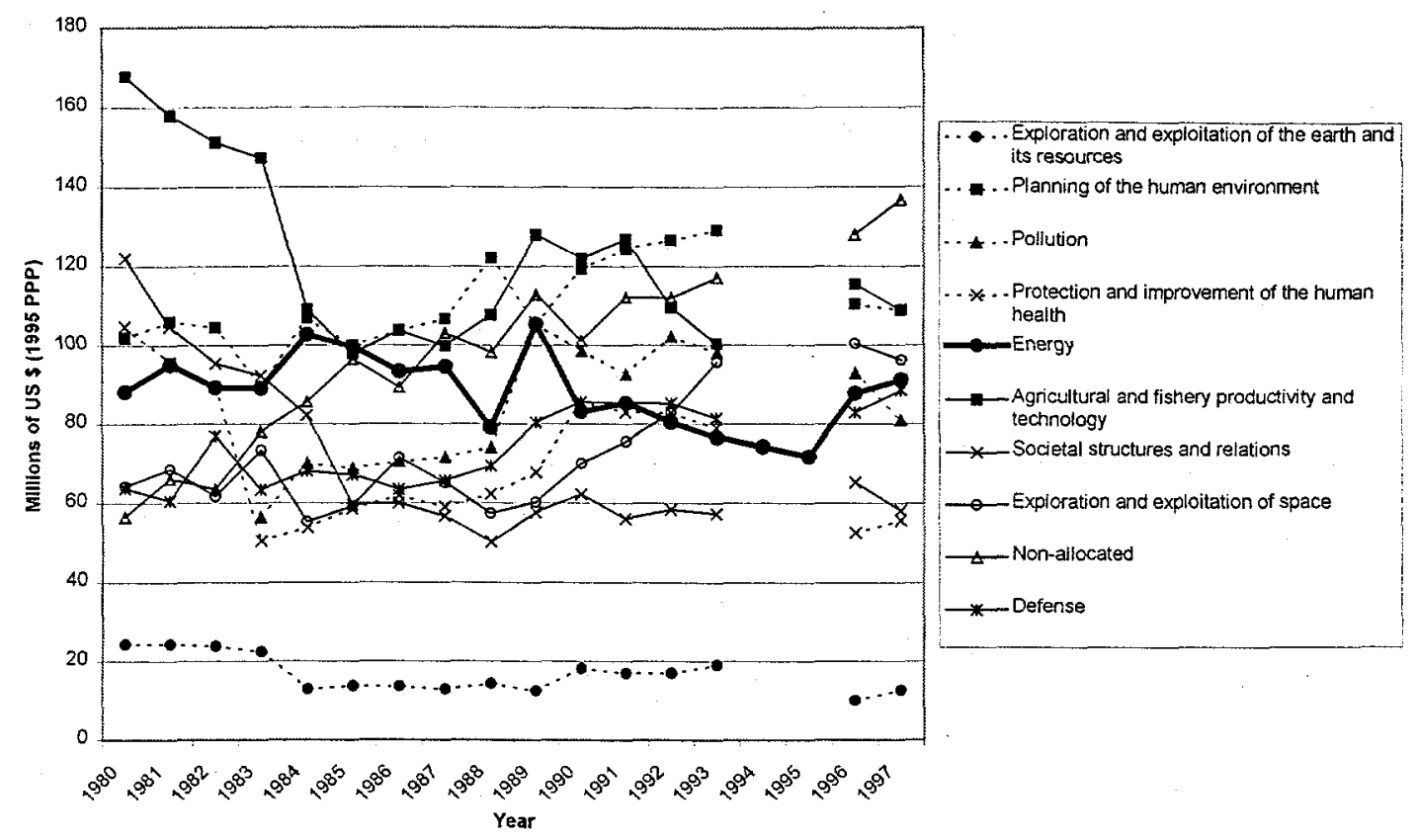

Energy R\&D has fluctuated between a high of $\$ 100$ million in 1985 and a low of $\$ 75$ million in 1995. This area has recovered recently, with budgets of approximately $\$ 90$ million in 1996 and 1997 . Some of the fluctuation in the energy R\&D budget can be attributed to changes in the composition of governmentsupported energy R\&D. For example, with the waning importance and public acceptance of nuclear energy in the Netherlands, 10 the government budget for nuclear research has decreased in the last few years (currently about $25 \%$ of energy budget, down from $35 \%$ in 1990). The budget for renewable energy $R \& D$, on the other hand, has increased steadily in recent years, from about $3 \%$ in 1990 to its current level of 7\% (Ministry of Education, Culture, and Sciences, yearly report).

\section{An Overview of Dutch Science and Technology Policy}

Throughout the 1990s the Dutch government has worked to develop a more thoughtful and selective approach to its allocation of R\&D resources (both in the national Technology Policy (Ministry of Economic Affairs) and in the Science Policy (Ministry of Education, Culture and Sciences)). This approach is driven, in part, by budgetary considerations and also by the realization that knowledge is increasingly important to the overall health of the economy. One aspect of this more thoughtful and selective approach to funding $R \& D$ is the government's desire to fund research in selected strategic research areas (e.g., energy R\&D) that can simultaneously meet both businesses' needs and societal needs (Ministry of Education, Culture, and Sciences, 1997). An extensive strategic foresight activity was started in 1992 (see OCV, June 1996).

In 1995, the policy strategy document "Knowledge in Action" was published both by the Ministry of Economic Affairs and by the Ministry of Education. This policy document formalized much of the government's new thinking about science and technology policy. One of its central ideas was the need to increase the "interaction between producers and consumers of new knowledge." That is, the government

\footnotetext{
${ }^{10}$ After the closure of the Dodewaard reactor, Borssele will be the only nuclear power generation facility in the Netherlands. The Borssele facility is to be shut down in 2004.
} 
needed to find new ways to increase cooperation and interaction between private firms and the semipublic research institutes to actually increase the application of knowledge generated. One avenue for increasing this interaction would be to give firms a larger and more formal role in helping the government set new research priorities (e.g., through Foresight Activities or setting research programs for semi-public research institutes). 11

Another change in the government's science policy - in line with the mentioned way of thinking - is the previously mentioned changes in the way universities and semi-public research institutes are supported. In particular, the government is attempting to move these institutions' support away from block grants and towards a system that is more based upon merit. For example, the share of direct funding ("first flow" or block grants, which are known in many other countries as General University Funds) decreased from $62.2 \%$ to $55.7 \%$ between 1986 to 1996 (VSNU, 1997). As a result, universities are becoming more and more dependent on the "second flow" (merit-based or peer-reviewed) grants. In addition, universities have been encouraged to increase their contract research activities with the private sector (the so called "third flow" 12 of resources) (Tijssen et al., 1998).

The semi-public research institutes (e.g., the Netherlands Energy Research Foundation (ECN) ${ }^{13}$ and the Netherlands Organization for Applied Scientific Research (TNO)) are being encouraged "to operate in a market-oriented way." To accomplish this, the government is subjecting the direct subsidy it provides to these institutes to an increasing level of input from the "demand side," i.e., the private sector. The government believes that, by directly involving the private sector in setting priorities for the research carried out at universities and semi-public research institutes, the private sector will be more likely to make use of research results.

The private sector is being encouraged to increase its own R\&D efforts through an expanded R\&D tax credit. 14 The private sector is also being encouraged to increase its partnership activities with other firms, with universities, and with semi-public research institutions. Currently, most government R\&D programs 15 require private firms to partner with other $R \& D$ providers as a condition for receiving support.

The ultimate goal of these new government initiatives extends beyond the quantitative growth of the $\mathrm{R} \& \mathrm{D}$ enterprise. The new programs are also seeking to stimulate technological innovation in the Netherlands and to ensure the more efficient application, commercial and otherwise, of the knowledge generated by the nation's R\&D networks.

\footnotetext{
${ }^{11}$ See, for exapmle., OCV, February 1996 and OCV, June 1996.

${ }^{12}$ The "third flow" of resources is defined as funding for reseach that comes directly from third parties such as the European Union and private companies.

${ }^{13}$ The ECN was transformed in the late 1970s from a nuclear energy R\&D centre to a laboratory that is predominantly focused on long term energy research. Currently, ECN is financed through three lines: (1) the cooperative financing programme aims at co-operation with companies in developing technologies, which are applicable in the short to near term (cost-sharing). Steering committees (involving representatives from market parties) guide the priorities in research; (2) the second line concerns the long-term "Energy Generation in a Natural Environment" (ENGINE) programme. Representatives form the energy sectors, companies, universities and the government are involved in formulating the programme; (3) the basic subsidy of the Ministry of Economic Affairs is destined for facilitating and conditioning the first two lines.

${ }^{14}$ In 1997 , the government increased by $20 \%$ (to a total of $\$ 300$ million) the budget set aside to cover the R\&D tax credit. This governmental support is not covered in yearly R\&D statistics produced by the CBS.
} 


\section{NATIONAL ENERGY POLICY}

As Figure 5 shows, the dominant energy carrier in the Netherlands is natural gas. Natural gas is used extensively in the residential, industrial, and commercial sectors. Oil is mainly used in transport, refineries, and the petrochemical industry. Coal is mainly used in the iron and steel industry and in electricity production.

Figure 6: Netherlands Total Primary Energy Demand for 1996 (CBS, 1996)

\subsection{Quads}

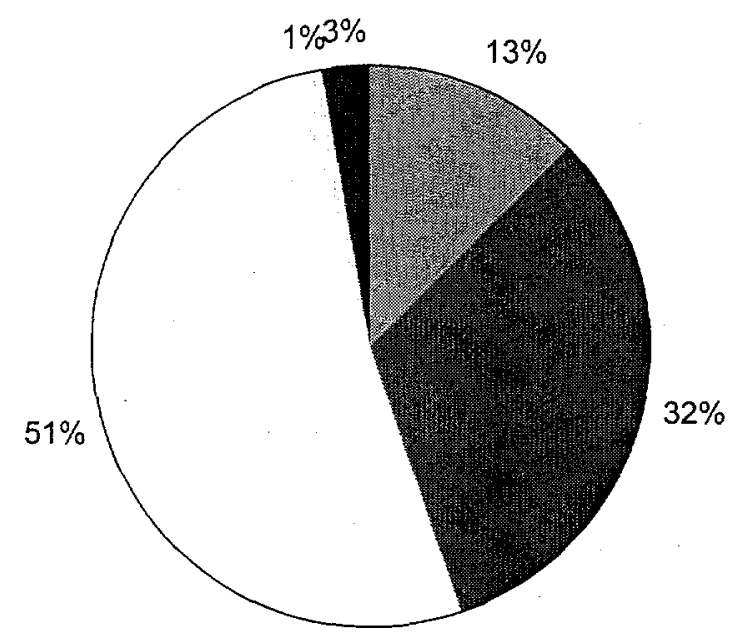

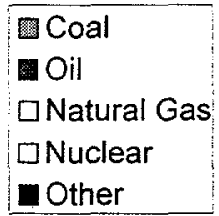

Coal

aNatural Gas

Other

Table 1: 1996 Energy Snapshot 16

\begin{tabular}{|c|c|}
\hline Dependence on energy imports: $68 \%$ & $\begin{array}{l}\text { Carbon emissions }[1995]^{17} \text { : } \\
\mathrm{CO}_{2}: 48 \text { million tons of carbon } \\
\text { All GHG's: } 58 \text { million tons of carbon } \\
\text { Equivalent }\end{array}$ \\
\hline $\begin{array}{l}\text { Energy Consumption per capita: } \\
188 \text { million Btu/capita ( } 198 \mathrm{GJ} / \text { capita) }\end{array}$ & $\begin{array}{l}\text { Carbon emissions per unit GDP [1995]: } \\
\mathrm{CO}_{2}: 0.16 \mathrm{~kg} \text { carbon } / \$(0.07 \mathrm{~kg} \text { carbon } / \mathrm{fl}) \\
\text { All GHG's: } 0.19 \mathrm{~kg} \text { carbon (eq.) } / \$(0.09 \\
\text { carbon (eq. }) / \mathrm{fl})\end{array}$ \\
\hline $\begin{array}{c}\text { Energy Consumption per unit GDP }(\mathrm{EI}) \text { : } \\
9.2 \text { thousand Btu/ } \$(4.7 \mathrm{MJ} / \mathrm{fl})\end{array}$ & $\begin{array}{l}\text { Carbon emissions per capita: } \\
\qquad \mathrm{CO}_{2}: 3.1 \text { tons carbon/capita } \\
\text { All GHG's: } 3.7 \text { tons carbon (eq.)/capita }\end{array}$ \\
\hline $\begin{array}{l}\text { "Kyoto commitment": } 6 \% \text { reduction in GHG } \\
\text { emissions from } 1990 \text { levels by } 2008-2012\end{array}$ & $\begin{array}{l}\text { Fossil fuel import dependence } \\
\text { Oil: } 98 \% \\
\text { Gas: } 56 \% \\
\text { Coal: } 98 \%\end{array}$ \\
\hline
\end{tabular}

${ }^{16}$ Energy data from (CBS, 1996).

${ }^{17} \mathrm{CO}_{2}$-emission data from (CBS, 1997). 


\section{Energy Policy}

Since the oil crises of the 1970s and 1980s, the general objective of Dutch energy policy has been to provide the Netherlands with adequate supplies of reliable, affordable and clean energy. The Dutch energy policy, as formulated in the most recent White Paper on Energy Policy (December 1995), has two pillars. The first aim is a gradual liberalization of the Dutch electricity and gas markets. The second is to achieve a $33 \%$ energy efficiency improvement (with respect to a base year of 1995 ) and a $10 \%$ share of renewable energy in total primary energy consumption by the year 2020 .

Liberalization - Under the White Paper's proposals, the number of "captive consumers" in both electricity and natural gas markets will be steadily reduced. The basic nature of the market will be thus transformed from being supply-driven to being more demand-driven. In principle, third-party access to the electricity and natural gas grids must be provided on a non-discriminatory basis. Contracts with end-users will replace central planning. Previously the electricity production market in the Netherlands was heavily regulated under the Electricity Act of 1989. However, in July 1998 a new Electricity Act was adopted, mandating the complete liberalization of the electricity generation sector by 2007 . This liberalization also extends to the import and export of electricity. Large consumers (33\% of the market) will be free to choose their suppliers starting in 1999. A second group, constituting an additional $29 \%$ of the market, will be allowed to choose its suppliers as of 2002 . Small consumers, making up some $38 \%$ of the market, will be allowed to choose their electricity providers only in 2007 . The traditional roles of electricity production companies and electricity distribution companies are also being redefined. The Act also includes regulations regarding the introduction of renewable energy. 18

Government regulation also has a significant influence on the market organization and production of natural gas. However, in contrast to the electricity market, large natural gas consumers ${ }^{19}$ are already free to choose their suppliers. The import and export of natural gas are also largely unregulated at this point. Because of European Union regulations that were adopted in 1994,20 producers are no longer obliged to sell natural gas solely to Gasunie, formerly the Netherlands' monopoly gas producer (Ministry of Economic Affairs, 1995). 21 A revised Gas Act will likely be introduced in the Second Chamber of Parliament in 1999.22 The revised Gas Act is expected to provide for a further deregulation of the natural gas market that would parallel the deregulation of the electricity market, i.e., consumers would be allowed to choose their supplier of natural gas when they are allowed to choose their electricity supplier. The revised Gas Act will also likely include requirements for the further promotion of energy efficiency. Mining legislation is expected to continue regulating the exploration and production of natural gas in the liberalized market.

The Netherlands has been neither a laggard nor a leader among industrialized countries in liberalizing their energy markets. The United States, Canada and the United Kingdom are a step ahead; Germany is approximately at the same stage in the process, while other countries appear to be lagging behind. The government believes that in addition to reducing prices, liberalization will also improve the delivery of energy services to consumers (Ministry of Economic Affairs, 1995). That said, the government is still

\footnotetext{
${ }^{18}$ See Ministry of Economic Affairs, 1996 and the text of the Electricity Act 1998, July 2, 1998.

${ }^{19}$ Large natural gas consumers are defined as consuming more than 10 million $\mathrm{m}^{3} /$ year. Large natural gas consumers account for about $46 \%$ of the market (Ministry of Economic Affairs, 1995).

${ }^{20}$ RL 94/22/EG, PB. 1994, L 164.

${ }^{21}$ Gasunie is a gas trading and transmission company. Its primary activities are buying, carrying, and selling natural gas destined for the Dutch and export markets. Gasunie is owned $50 \%$ by the Government, $25 \%$ by Shell (gas and oil firm), and $25 \%$ by Esso (gas and oil firm).

${ }_{22}^{22}$ Press release by the Ministry of Economic Affairs (02-11-1998).
} 
uncertain how deregulation will affect existing voluntary agreements with the utilities to strive to meet certain efficiency goals.

Energy Efficiency and Renewable Energy - The second major aim of Dutch energy policy is to continue the implementation of energy efficiency policy as formulated in 1990 and 1993 (Ministry of Economic Affairs, 1990 and 1993) and to pursue an active policy to realize 10\% share of renewable energy in total primary energy consumption by the year 2020 (see Table 2). Policy to stimulate energy efficiency and renewable energy was further developed in April 1998 and March 1997 respectively

Since 1990, Dutch energy efficiency policy has not only been motivated by a desire to reduce the country's dependence on energy from OPEC countries but also by a desire to protect and improve the environment. Given that climate change is believed to be caused by the use of fossil fuels, policy measures designed to combat climate change are, to a large extent, formulated within Dutch energy policy.

The Ministry of Economic Affairs reformulated its energy efficiency policy in the aftermath of the Kyoto Climate Change Conference. Both the agreements made in Kyoto and the high economic growth in The Netherlands over the past few years necessitated the upward revision of the national energy efficiency target from $1.6 \%$ to $2.0 \%$ per year.

In a recent Memorandum on Energy Saving (1998) (which is currently a non-binding consultation document), the Ministry suggested that meeting this increased energy efficiency goal required considerable investments by the Dutch economy (about $\$ 1.5$ to $\$ 2$ billion a year) and that the government's contribution to the effort will be $\$ 300$ million per year. The Memorandum also emphasized the need for more active measures to stimulate energy efficiency (Ministry of Economic Affairs, April 1998a). For example, in the past energy efficiency improvements were largely the result of Voluntary Agreements and self-regulation. In the future, Dutch energy policy will, in addition to the line of Voluntary Agreements, adopt performance standards, regulation, and fiscal stimulation to encourage further energy efficiency improvements. The government envisions targeted programs for different sectors of the Dutch economy (e.g., households, commercial buildings, agricultural sector, industry, SME's, transport, and the energy sector). Besides ideas such as benchmarking to stimulate industrial energy efficiency, an increasing focus on industrial areas, and stricter performance standards for energy efficiency in houses and utility buildings, RD\&D also has a role to play. For example, the government will support $R D \& D$ for energy efficiency demonstration projects in the built environment, $R \& D$ for the horticultural sector (e.g., to support cogeneration projects), and R\&D for industrial energy efficiency "breakthrough technologies" (creating step-function improvements in energy efficiency) (Ministry of Economic Affairs, 1998a).

As suggested in the White Paper, the Action Programme for Renewable Energy (1997-2000) was launched early in 1997 (Ministry of Economic Affairs, March 1997). The Action Programme is addressing three lines of thought: improving the price-performance ratio of renewable energy technologies through research, stimulating the market penetration of renewable energy technologies, and tackling administrative bottlenecks that frustrate the deployment of these technologies. In addition to increasing various subsidies and other fiscal stimulation measures designed to speed the market introduction of renewable energy technologies, 23 the renewable energy R\&D budget of the Ministry of

\footnotetext{
${ }^{23}$ Some of the fiscal stimulation measures for renewable energy technologies include the Energy Tax for Small Households and SME's (January 1, 1996), the Accelerated Depreciation of Environmental Investments (VAMIL), the Green Funds (started in 1995), and the Energy Investment Relief Scheme (IEA).
} 
Economic Affairs increased considerably between 1996 and 1997 (see Table 3). A specific initiative mentioned in the White Paper is the establishment of a Project Agency for Renewable Energy that would comprise EnergieNed, 24 the four Dutch energy production companies, 25 industrial partners, and the Ministry of Economic Affairs. This Project Agency is currently being established and is intended to play a catalyzing role in realizing renewable energy projects (located in Arnhem).

The Third White Paper on Energy (1995) admits that the targets formulated for energy efficiency and renewable energy require both investments in the development of new technologies and fiscal stimulation (such as subsidies and tax breaks) for technology demonstration and deployment. The White Paper indicates industrial energy conservation, photovoltaics, biomass and wind energy as priorities for energy R\&D. At the same time, the consequences of energy liberalization on the amount and the type of investments in energy R\&D are uncertain (Ministry of Economic Affairs, 1995).

Table 2: Projected Renewable Energy Usage in the Netherlands (Ministry of Economic Affairs, 1995)

\begin{tabular}{|l|r|r|r|}
\hline Contribution in PJ (saved primary energy) & 2000 & 2007 & 2020 \\
\hline Wind energy & 16 & 33 & 45 \\
\hline Photovoltaic energy & 1 & 2 & 10 \\
\hline Thermal solar energy & 2 & 5 & 10 \\
\hline Geothermal energy & - & - & 2 \\
\hline Storage of heat and cold in aquifers & 2 & 8 & 15 \\
\hline Heat pumps & 7 & 50 & 65 \\
\hline Hydroelectric power & 1 & 3 & 3 \\
\hline Energy from biomass and waste & 54 & 85 & 120 \\
\hline Imported Norwegian hydroelectric power & - & 18 & 18 \\
\hline Total (including import) & 83 & 204 & 288 \\
\hline
\end{tabular}

Energy $R \& D$ Policy - In line with the strategies formulated in "Knowledge in Action," the Ministry of Economic Affairs wants to increase the role of the energy sector in formulating energy R\&D priorities. The government hopes that by increasing the private sector's consultative role and by encouraging private financial contributions to energy $R \& D$ projects, it will be better able to prioritize publicly funded energy research, guarantee an appropriate total level of energy R\&D, and avoid the emergence of a gap between public and private R\&D efforts (Ministry of Economic Affairs, 1995). To facilitate future involvement of the private sector in energy $R \& D$ priority setting, an extensive survey of the energy $R \& D$ supply and demand sides was performed preparatory to the White Paper (performed by Arthur D. Little and PA Consultancy, June 1997). The results of this survey are currently being used to improve the coordination among various elements of the "energy knowledge infrastructure."

This survey and the earlier-mentioned activities of a Strategic Foresight Committee resulted in the formulation of a public energy R\&D policy (Ministry of Economic Affairs, April 1998b) (see also the section on Key Technology Areas).

\footnotetext{
${ }^{24}$ EnergieNed represents the interests of the Dutch utility distribution companies and is charged with implementing the Environmental Action Plan (MAP). It is supported by a small levy on electricity and natural gas consumption. This budget is used to support, among other things, the introduction of renewable energy technologies.

${ }^{25}$ UNA, EPZ, EPON and EZH.
} 
A comparison of Tables 2 and 3 shows that photovoltaic energy is intended to receive the largest share of the energy $R \& D$ budget, while its contributions to the energy goals formulated are modest.

Table 3: Budget for Renewable Energy (Ministry of Economic Affairs, 1997)

\begin{tabular}{|l|r|r|r|r|r|}
\hline Millions of US\$ (1995 PPP) & 1996 & 1997 & 1998 & 1999 & 2000 \\
\hline Research program: wind energy & 4.1 & 7.7 & 7.7 & 7.7 & 7.7 \\
\hline Research program: photovoltaic energy & 5.8 & 15.5 & 15.8 & 15.9 & 15.9 \\
\hline Research program: energy from biomass and waste & 3.6 & 7.2 & 7.2 & 7.2 & 7.2 \\
\hline Research program: thermal solar energy & 3.1 & 4.0 & 4.0 & 4.0 & 4.0 \\
\hline Program: heat pumps & 2.5 & 3.8 & 3.8 & 3.8 & 3.8 \\
\hline Project Agency Renewable Energy & - & 2.3 & 2.3 & 2.3 & 2.3 \\
\hline Basic / goal subsidy ECN & 4.6 & 4.6 & 4.6 & 4.6 & 4.6 \\
\hline Goal subsidy TNO & 0.7 & 0.7 & 0.7 & 0.7 & 0.7 \\
\hline "Economy, Ecology, Technology" Program26 & 4.7 & 4.7 & 4.7 & 4.7 & 4.7 \\
\hline Total (including subsidies) & 33.8 & 53.3 & 50.7 & 50.7 & 50.7 \\
\hline
\end{tabular}

$\mathrm{CO}_{2}$ Emission Reductions - In addition to the Energy Policy, the Dutch government is pursuing activities within the framework of climate policy. The Dutch government recently announced a major initiative designed to reduce $\mathrm{CO}_{2}$ emissions, exemplifying the government's attitude towards $\mathrm{CO}_{2}$ emission reductions and investments in energy $R \& D$. In 1997 the government allocated $\$ 750$ million for intensifying climate policy to reduce $\mathrm{CO}_{2}$ emissions. 27

About $\$ 500$ million is allocated to the " $\mathrm{CO}_{2}$-reduction plan." The initiative focuses on large-scale investment projects that will substantially decrease $\mathrm{CO}_{2}$-emissions. Twelve projects are currently supported. A second tender is currently open. Cost effectiveness in tonnes $\mathrm{CO}_{2}$ emissions avoided is used as the explicit criterion for selecting projects. Areas of interest are the recovery of industrial waste heat, development of heat pumps and advanced cogeneration, membranes, energy infrastructure in horticultural and new residential areas and the realization of an offshore wind energy park.

The continuing budget of $\$ 250$ million is being used to support projects in several areas, including joint implementation (i.e., working with developing nations), reduction of greenhouse gases other than carbon dioxide, carbon sinks, breakthrough energy conservation technologies, 28 transportation research, and clean bio-fuels (see also Key Technology Area).

Lastly, with the recent installation of the new government in The Netherlands (August 1998), the stimulation of energy efficiency and renewable energy was again emphasized explicitly. The government's intention is to increase the current Ecotax. Of the total revenue generated by the Ecotax, the plan is to use $15 \%$ (about $\$ 250$ million) for fiscal stimulation of energy efficiency. An additional $\$ 40$ million will be allocated for renewable energy R\&D during the period 1999-2002 (mainly photovoltaic solar energy) 29 (Regeerakkoord, 1998).

\footnotetext{
${ }^{26}$ This figure represents an approximation of the share of the Economy-Ecology-Technology Programme's budget devoted to renewable energy.

${ }^{38}$ Personal communication, Mr. K.J. Koops, Ministry of Economic Affairs, November 1998.

${ }^{28}$ This budget might be used to implement many of the policy initiatives mentioned in the recent Memorandum on

Energy Conservation (Ministry of Economic Affairs, April 1998).

${ }^{29}$ For the period $1999-2010$, a total of $\$ 400$ million is reserved for the promotion of renewable energy.
} 


\section{ENERGY TECHNOLOGY TRENDS}

Except for the data covered in the science budgets (see Figures 3, 4, and 5), there are no robust time series data for either public or private energy R\&D expenditures in the Netherlands. 30 However, with the increased attention being paid to energy $R \& D$ and the value of energy $R \& D$ in meeting certain national goals, a number of studies have recently been conducted that help to create some insight into Dutch energy R\&D, its orientation, and its organization. 31

A brief historical overview of changes in Dutch energy R\&D activity and current priorities in energy R\&D, which were recently formulated by the Ministry of Economic Affairs will be presented (Ministry of Economic Affairs, April 1998b), before a more detailed description of government energy R\&D programs.

\section{Historical Changes in Energy Priority Areas}

Since the first oil crisis in 1973, the Netherlands government has funded RD\&D in non-nuclear energy technologies (AER, July 1996). The first White Paper on Energy (1974) mentioned the need to reduce dependency on imported OPEC oil and environmental considerations as reasons why the government should support energy R\&D. 32 In these early years of the Dutch energy R\&D program, energy R\&D priorities were (1) conservation (rational energy use in the building sector, transport and industry; possible ways to store energy; reductions in energy conversion losses); (2) diversification of energy supplies (reintroduction of coal and the introduction of nuclear power); and (3) the development of "national" domestic energy sources (e.g., solar energy, wind energy and geothermal energy). Dutch public energy R\&D was coordinated by the Project Agency on Energy Research (PEO) until 1988 when Novem took over these responsibilities. 33 Table and 5 give an impression of the changes in priority areas for energy $R \& D$ in the Netherlands.

Even though PEO's and Novem's budgets do not fully represent the total energy R\&D expenditure of the Dutch government (especially natural gas related research and nuclear research are missing from these programmatic budgets), they do give a rough indication of changes in priority for energy R\&D. For example, the budget devoted to coal has been reduced substantially over time. Originally coal was seen as a significant option for diversifying the nation's energy supplies. However, because of environmental problems associated with coal combustion, the availability of large stocks of natural gas, and the successful implementation of gas-fueled combined heat power (CHP) in the Dutch energy system, coal has been replaced by natural gas as the dominant fuel.

\footnotetext{
${ }^{30}$ The data historically submitted to the IEA (Paris) exhibit some systematic differences in recent yearly reports (data collected by $\mathrm{M}+\mathrm{I}$ Consultancy (Amsterdam) and currently by Ecofys (Utrecht) (Personal communication, Mr. D. de Jager, Ecofys, February 1999).

${ }^{31}$ See, e.g., Weijnen, 1994; Wees and van Wijk, September 1995; OCV/VCE, February 1996; AER, July 1996; Arthur D. Little and PA Consultancy, June 1997; CBS, September 1997; Struker and de Jager, 1998; Senter, 1997; Ministry of Economic Affairs, April 1998 b.

${ }^{32}$ Environmental considerations were the quality of air, soil, and water, and spatial planning.

${ }^{33}$ In 1988, Novem became the administrator of most of the non-nuclear governmental programs (covering research, development, market introduction, and knowledge transfer). The purpose of this public corporation is to contribute to improving the Netherlands' energy and environmental situation. Novem carries out a number of programs on research and dissemination of energy efficient technologies and renewable energy resources, which are commissioned by the Ministry of Economic Affairs (and increasingly are also cofunded by other institutions). Most of the programs are carried out on a cost-shared basis although the data above do not include these external contributions. Novem is not responsible for implementing the total energy RD\&D budget.
} 
Table 4: Cumulative Spending on Non-Nuclear Energy R\&D (PEO) 1973-1986 34

\begin{tabular}{|l|r|r|}
\hline Energy R\&D Area & $\begin{array}{r}\text { [\$ million] } \\
\text { 1995 US \$ }\end{array}$ & $\begin{array}{l}\text { l of } \\
\text { budget }\end{array}$ \\
\hline Coal & 70 & $25 \%$ \\
\hline Wind energy & 64 & $22 \%$ \\
\hline Solar energy & 33 & $12 \%$ \\
\hline Reuse of waste & 8 & $3 \%$ \\
\hline Geothermal energy & 5 & $2 \%$ \\
\hline Rational use of energy building sector & 31 & $11 \%$ \\
\hline Rational use of energy industry & 11 & $4 \%$ \\
\hline Rational use of energy transport & 11 & $4 \%$ \\
\hline $\begin{array}{l}\text { Energy saving appliances (e.g., heat } \\
\text { pumps, fuel cells, also boilers) }\end{array}$ & 36 & $13 \%$ \\
\hline Other & 14 & $5 \%$ \\
\hline Total & $\sim 284$ & \\
\hline
\end{tabular}

The budget devoted to energy efficiency R\&D (whether industrial, residential, or transport) has increased substantially over time. By now, it is the dominant area of public and private energy RD\&D in the Netherlands (Struker and de Jager, 1998; Senter, 1997).

The Netherlands has a long history of supporting renewable energy projects. Wind energy was the first renewable option that received substantial support from the government. The first National Research Programme started in 1976 (1976-1981). R\&D in wind is however decreasing lately.

A national research program on solar energy (only thermal solar energy) started in 1978. Stimulation of photovoltaic solar energy started in the $1980 \mathrm{~s}$. The budget available for PV is growing recently (see also Table 3). Biomass is the most recent renewable energy option to receive growing interest. This biomass research started mainly in the waste area (e.g., co-combustion, cleaning of flue gasses, conversion efficiencies of waste incinerators, availability of waste material) and shifted its focus more and more towards biomass (e.g., different conversion routes, gasification etc.). Although modest in budget, geothermal energy has received attention since the initiation of the Dutch public sector R\&D effort.

Since 1990, Dutch energy conservation programs and programs designed to explore and exploit domestic energy sources (e.g., renewable energy and natural gas) are increasingly motivated by environmental arguments as opposed to the previous decades' rationale of reducing the dependency on OPEC countries. The development of "national" domestic energy sources (e.g., solar energy, wind energy and geothermal energy) was continued under a changed argument.

Energy research has received increasing attention since the early $1990 \mathrm{~s}$, for example, through the activities of the Strategic Foresight Committee in 1992 (OCV, February 1996 and June 1996). In Appendix 1 the current organization of energy R\&D programming and financing is shown. The committee concluded that publicly financed energy R\&D should facilitate a change towards an energy system that supports "sustainable development." Both energy efficiency and the introduction of renewable technologies (solar energy, wind energy, and biomass) were favored for the long term. The

\footnotetext{
${ }^{34}$ About half of the total governmental spending on energy R\&D in this period ( $\$ 560$ million) was implemented through the Project Agency on Energy Research (PEO, 1987). All data are taken from PEO 1987.
} 
expanded and more efficient use of natural gas is seen as a suitable option in the transition towards a sustainable energy system.

Table 5: Novem Programme Budget 35

\begin{tabular}{|l|r|r|r|r|r|r|}
\hline & 1986 & 1987 & 1990 & 1992 & 1995 & 1997 \\
\hline $\begin{array}{l}\text { Programme budget } \\
\text { [millions of US\$(1995 PPP)] }\end{array}$ & 41 & 50 & 160 & $\begin{array}{r}149 \\
{[155]}\end{array}$ & $\begin{array}{r}94 \\
{[103]}\end{array}$ & $\begin{array}{r}111 \\
{[125]}\end{array}$ \\
\hline $\begin{array}{l}\text { Rational energy use in } \\
\text { industry }\end{array}$ & $14 \%$ & $10 \%$ & $25 \%$ & $35 \%$ & $33 \%$ & $38 \%$ \\
\hline $\begin{array}{l}\text { Rational energy use in } \\
\text { transport }\end{array}$ & $5 \%$ & $3 \%$ & - & $2 \%$ & $4 \%$ & $4 \%$ \\
\hline $\begin{array}{l}\text { Rational energy use in the } \\
\text { building sector }\end{array}$ & $9 \%$ & $10 \%$ & $9 \%$ & $7 \%$ & $8 \%$ & $10 \%$ \\
\hline $\begin{array}{l}\text { Appliances (e.g. heat pumps, } \\
\text { fuel cells, CHP) / Long term } \\
\text { technologies }\end{array}$ & $15 \%$ & $7 \%$ & $11 \%$ & $9 \%$ & $9 \%$ & $7 \%$ \\
\hline Coal (\& Energy supply) & $20 \%$ & $20 \%$ & $7 \%$ & $5 \%$ & $3 \%$ & $6 \%$ \\
\hline Wind energy & $12 \%$ & $26 \%$ & $10 \%$ & $20 \%$ & $21 \%$ & $6 \%$ \\
\hline Solar energy & $6 \%$ & $8 \%$ & $13 \%$ & $5 \%$ & $7 \%$ & $13 \%$ \\
\hline Reuse of waste heat & $11 \%$ & $7 \%$ & $6 \%$ & $3 \%$ & $3 \%$ & $1 \%$ \\
\hline $\begin{array}{l}\text { Energy from waste and } \\
\text { biomass }\end{array}$ & & & $6 \%$ & $2 \%$ & $4 \%$ & $5 \%$ \\
\hline $\begin{array}{l}\text { Geothermal energy and heat } \\
\text { storage in aquifers }\end{array}$ & $6 \%$ & $8 \%$ & $1 \%$ & $1 \%$ & $<1 \%$ & $<1 \%$ \\
\hline Environmental technology & - & - & $4 \%$ & $3 \%$ & $2 \%$ & $3 \%$ \\
\hline $\begin{array}{l}\text { De-Nox/low NOx turbines } \\
\text { and motors }\end{array}$ & - & $-5 \%$ & $4 \%$ & - & - \\
\hline Measurement methods & - & - & - & $1 \%$ & $1 \%$ \\
\hline Policy studies & $-3 \%$ & $3 \%$ & $5 \%$ & $6 \%$ \\
\hline
\end{tabular}

As mentioned earlier, the Committee Report and the White Paper on Energy induced an extensive analysis of the supply and demand side of Dutch energy R\&D (Arthur D. Little and PA Consultancy, June 1997). The main conclusions stemming from this analysis are embodied in a Memorandum to the government on energy R\&D priorities published by the Ministry of Economic Affairs (April 1998b):

- The quality of energy R\&D in the Netherlands is generally good. However, both the efficiency of energy R\&D and the "sustainable" character of the activities performed can be increased. The government believes (1) the organization of energy R\&D should be improved, (2) the priorities in energy R\&D should be formulated clearly to anticipate international agreements to reduce $\mathrm{CO}_{2}$ emissions, (3) energy R\&D programs should take into account the liberalization of the energy markets, and (4) the administration of energy R\&D programs should facilitate decision-making in "buying" or "developing" new technologies.

\footnotetext{
${ }^{35}$ Data for this table are taken from Novem, various yearly reports.

${ }^{36}$ The figure in the bracket includes contributions from other public sources such as other Dutch ministries, by programs of the Paris-based International Energy Agency (e.g., Heat Pump Centre, GreenTie, CADDET Energy Efficiency) and the European Union.
} 
- The Ministry of Economic Affairs will initiate foresight activities for new-long term energy R\&D areas of interest.

- To stimulate energy R\&D at universities (currently estimated at \$35-40 million per year), the government will seek to foster greater coordination of university energy R\&D (through NWO). The government intends to launch this "Stimulation Programme for University Energy R\&D" early in 1999.

- Along these same lines, the government will seek to foster greater coordination among the semipublic energy research institutes. This is being done to reduce overlap and redundancies and to hopefully create synergy among the research projects carried out at these institutions. Even though the current liberalization of the energy sector is creating a rather dynamic and changing context for this industry, the Ministry of Economic Affairs is still attempting to formalize the role of the energy sector in setting priorities for energy $R \& D$ and in defining the role of semi-public and private research institutes that engage in energy $R \& D$.

- The government will pay more attention to the non-technical - socioeconomic - aspects (so-called "gamma-research") of the deployment of new technologies (e.g., non-technical factors that influence diffusion of renewable energy technologies).

- Future energy efficiency R\&D programs should emphasize more basic and more crosscutting research in areas such as advanced catalysts, biotechnology, advanced control of processes, and sensors.

- On the other hand, the increasingly decentralized and liberalized energy supply system implies that the focus of programs designed to commercialize energy technologies (e.g., renewable energy, energy efficiency, and energy infrastructure technologies) should shift from a component level to a system-level perspective.

- The government will step up its efforts to facilitate the introduction of (renewable) decentralized electricity generation and supporting technologies (e.g., grid stabilization, grid optimization, and storage).

- The government will initiate a new research program for the production and application of renewable synthetic gasses and fuels will be initiated (e.g., hydrogen, bio-gasses and bio-fuels/GAVE program). The budget for this new program will be approximately $\$ 20$ million, supported out of the funds set aside for the intensification of climate policy initiative.

- The government will continue to support export-related activities for clean coal technologies, but will continue to reduce the budget for the further development of clean coal technologies.

- Although recognizing that a lack of public support makes it unlikely that the Dutch energy system will use nuclear power on any significant scale, the government will continue to support a level of nuclear R\&D that will allow reintroduction of nuclear power if the need should arise. 37 The government will also continue to participate in international fusion research (application $>2050$ ) for much the same reasons.

- The government will support a modest budget (approximately $\$ 2.5$ million over the period 19982000) for supporting a private-public partnership for renewable energy.

\footnotetext{
${ }^{37}$ The government argues that it should maintain a nuclear energy R\&D capability because of (1) the possible need to reintroduce nuclear power, (2) the possible occurrence of nuclear accidents elsewhere in Europe that would impact the Netherlands, (3) the obligation to take care of radioactive waste and the decommissioning of current nuclear plants, and (4) the spinoffs of nuclear energy $R \& D$ to medical research and pharmacology.
} 


\section{Quantitative Overview of Public Sector Energy R\&D}

Recently, two authoritative studies have mapped Dutch public and private sector energy R\&D activities. These surveys help to shed light not only on the scale of the Dutch energy R\&D effort, but also help describe who the major funders and performers of this energy R\&D are. 38

Table 6 shows the estimated support for energy RD\&D from the Dutch national government, related EU contributions, and related contributions of the nongovernmental sector for 1995, 1996, 1997

(estimated). ${ }^{39}$ Some interesting insights can be gleaned from Table 3 and from reports available on the state of Dutch energy R\&D:

- Best available data suggest that the private sector's energy R\&D investments are on par with the government's energy R\&D budgets. The proportion is almost 50:50.

- The majority of the private sector's energy R\&D investments are devoted to energy conservation. 40 Private sector investments also exceed those of the government in the area of power and storage technologies.

- In private R\&D investments, 3.0\% of the research was labeled energy R\&D (CBS, September 1997).

- Private companies partner with another entity in over $30 \%$ of the energy R\&D projects sponsored by the private firms; $90 \%$ of the time these private firms choose to partner with another private firm. However, the semi-public research institutes as TNO, KEMA, GasTec, ECN and NOVEM, as well as some of the larger national universities (Delft, Eindhoven, and Enschede) are also mentioned as significant partners for energy R\&D projects (Senter, 1997).

- Funds from the EU comprise approximately $6 \%$ of the total energy R\&D effort in the Netherlands (in 1997 approximately 10\%). The EU's funds are largely concentrated in supporting fission-related research.

- Renewable Energy R\&D, Nuclear Fission and Fusion, and the "Other" energy technology areas are predominantly financed by the public sector.

${ }^{38}$ The first survey, assessing Dutch governmental support to energy RD\&D, was performed by Ecofys Energy \& Environment (Utrecht). Novem financed the research project. All of the data in this section unless otherwise noted come from this first source (Struker and de Jager, 1998). It should be noted that these data cover public energy research, development and demonstration activities (RD\&D). Related private and EU spending are also included. However, these categories are not complete. These data include a rather small amount of funding for technology deployment activities in addition to funds for R\&D. Struker and de Jager (1998) estimate that approximately $95 \%$ of the total resources are spent on energy R\&D activities; only $5 \%$ are devoted to demonstration projects. Most of the demonstration funds are spent in the energy conservation and renewable energy projects. The second data source was generated by Senter (Zwolle). Senter, one of the policy implementing agencies of the Ministry of Economic Affairs, has a database that tracks private R\&D expenditures because of its role in implementing R\&D fiscal stimulation programs (Senter, 1998). Both surveys are currently being repeated (Personal communication, Mr. D. de Jager, Ecofys, February 1999). It has yet to be determined the extent to which the energy RD\&D projects covered in Ecofys' database are represented in Senter's database. A first explorative project is currently being performed to asses the overlap and/or the complementary character (Personal communication, Mrs. R. Bruel, Novem BV, February 1999).

${ }^{39}$ Research which is partly funded by government, induces expenditures of other sources. Nongovernmnetal expenditures are essentially private resources.

${ }^{40}$ This private sector dominance of energy efficiency R\&D is also evident in the data collected by Senter. The Senter study reports that the private sector accounts for about $53 \%$ of all energy efficiency R\&D in the Netherlands (Senter, 1997). 
Table 6: Support for Energy RD\&D in the Netherlands in millions of 1995 US Dollars 41

\begin{tabular}{|c|c|c|c|c|c|}
\hline & $\begin{array}{l}\text { IEA - Energy Technology } \\
\text { Classification }\end{array}$ & Public & $\begin{array}{r}\text { Related } \\
\text { EU } \\
\end{array}$ & $\begin{array}{l}\text { Related } \\
\text { Private }\end{array}$ & Total \\
\hline \multirow[t]{7}{*}{1995} & A - Conservation & 47.4 & 2.9 & 58.6 & 108.9 \\
\hline & B - Fossil Fuels & 12.1 & 1.4 & 13.0 & 26.5 \\
\hline & C-Renewable Energy Sources & 21.3 & 1.9 & 11.5 & 34.7 \\
\hline & D - Nuclear Fission and Fusion & 19.1 & 4.3 & 3.4 & 26.8 \\
\hline & E - Power and Storage Technologies & 14.2 & 2.4 & 18.8 & 35.4 \\
\hline & F - Other Cross-cutting Technology & 16.6 & 1.9 & 10.6 & 29.1 \\
\hline & Total & $\$ 130.7$ & $\$ 14.9$ & $\$ 115.7$ & $\$ 261.4$ \\
\hline \multirow[t]{7}{*}{1996} & A-Conservation & 50.5 & 2.8 & 79.3 & 132.6 \\
\hline & B - Fossil Fuels & 12.6 & 0.9 & 11.4 & 24.9 \\
\hline & C-Renewable Energy Sources & 21.6 & 2.8 & 14.2 & 38.7 \\
\hline & D - Nuclear Fission and Fusion & 17.0 & 4.3 & 3.8 & 25.0 \\
\hline & E-Power and Storage Technologies & 15.2 & 2.8 & 21.4 & 39.5 \\
\hline & F - Other Cross-cutting Technology & 12.9 & 2.4 & 8.1 & 23.4 \\
\hline & Total & $\$ 129.8$ & $\$ 16.1$ & $\$ 138.2$ & $\$ 284.1$ \\
\hline \multirow[t]{7}{*}{1997} & A - Conservation & 52.0 & 2.8 & 66.6 & 121.4 \\
\hline & B - Fossil Fuels & 10.8 & 0.9 & 10.8 & 22.6 \\
\hline & C-Renewable Energy Sources & 27.4 & 3.3 & 18.6 & 49.4 \\
\hline & D - Nuclear Fission and Fusion & 18.0 & 4.7 & 2.8 & 25.6 \\
\hline & E-Power and Storage Technologies & 14.4 & 2.8 & 22.0 & 39.3 \\
\hline & F - Other Cross-cutting Technology & 14.7 & 3.3 & 10.3 & 28.3 \\
\hline & Total & $\$ 137.4$ & $\$ 17.8$ & $\$ 131.3$ & $\$ 286.5$ \\
\hline
\end{tabular}

Figure shows the distribution of governmental support to the major areas in 1997. The Struker and de Jager (April 1998) study help to shed light on how the government funds energy R\&D (see also Figure 1 in Appendix 2).

- The Ministry of Economic Affairs finances approximately $65 \%$ of all publicly financed energy RD\&D. The Ministry of Education, Culture, and Sciences funds $27 \%$ of Dutch public sector energy RD\&D. The remaining $8 \%$ of public energy R\&D support come from a number of other Ministries. The contributions of the different financiers of energy RD\&D do not fluctuate very much over the three years covered (Struker and de Jager, April 1998).

- The vast majority of the energy R\&D funds supplied by the Ministry of Education, Culture, and Sciences (22\%) is used to support university based energy-research activities; $16 \%$ of the budget is funded directly, and $6 \%$ is channeled through NWO.

- Private sector entities perform approximately $30 \%$ of the publicly supported energy RD\&D. Engineering and consultancy firms perform 5\% of the public energy RD\&D. Small to medium-sized firms (fewer than 500 FTEs) perform approximately $15 \%$, while larger firms and utilities perform $7 \%$ and $3 \%$ respectively of the publicly supported research in the energy area.

- Novem distributed $46 \%$ of the public energy RD\&D (Struker and de Jager, April 1998). In 1996, the largest share of Novem's program budget was allocated to small to medium sized industrial firms

\footnotetext{
${ }^{41}$ Data are from Struker and de Jager, 1998. The figures for the European Union and the nongovernmental energy $R \& D$ programs represent figures related to the public spending on energy $R \& D$ and as such likely underestimate the energy $R \& D$ investments of these sectors.
} 
(<500 FTEs) (28\%). Another $11 \%$ was allocated to larger firms ( $>500$ FTEs). Respectively, $17 \%$ and $14 \%$ were allocated to semi-public research institutes (ECN and TNO) and to consultancies and engineering companies. Only 4\% of Novem's budget is allocated to universities (Novem, 1997).

- In $199619 \%$ of Novem's program budget was allocated to policy and feasibility studies, $45 \%$ to technology development, $12 \%$ to demonstration projects, and $24 \%$ to knowledge transfer and market introduction (Novem, 1997).

\section{Figure 7: Distribution of Dutch Governmental Support to Energy RD\&D} by major Technology Area (1997) 42

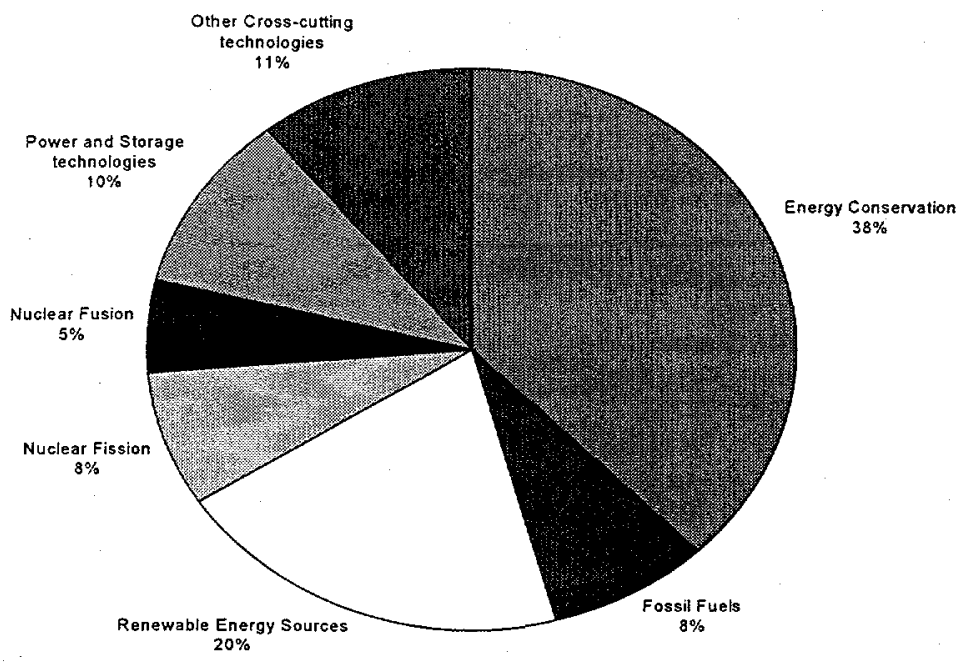

Table 5 shows the Dutch government's energy R\&D investments over the past three years at a lower level of aggregation than what appears in Table 4 . The data show that government support for energy RD\&D increased from 1995 to 1997 . Increases in the renewable energy $R \& D$ budget and in particular photovoltaic research largely account for this increase in the overall energy budget. The Dutch government's support for biomass and industrial energy efficiency research also received modest increases, while coal and light water reactor fission research saw reduced budgets.

Governmental support as reflected in these data has increased from 1995 to 1997 . Renewable energy $\mathrm{R} \& \mathrm{D}$ is largely responsible for this.

\footnotetext{
${ }^{42}$ Data are from Struker and de Jager, April 1998.
} 
Table 5: Support for Energy RD\&D

\begin{tabular}{|c|c|c|c|c|}
\hline & $\begin{array}{l}\text { IEA - Energy technology } \\
\text { classification [1995 US \$] }\end{array}$ & $\begin{array}{l}1995 \\
{[\text { million \$] }}\end{array}$ & $\begin{array}{l}1996 \\
\text { [million \$] }\end{array}$ & $\begin{array}{l}1997 \\
\text { [million \$] }\end{array}$ \\
\hline 1 & Total conservation & 47.4 & 50.5 & 51.6 \\
\hline 1.1 & Industry & 28.2 & 32.7 & 31.7 \\
\hline 1.2 & Residential \& services & 7.0 & 7.5 & 8.3 \\
\hline 1.3 & Transportation & 9.0 & 6.7 & 9.0 \\
\hline 1.4 & Other conservation & 3.1 & 3.6 & 2.9 \\
\hline 2 & Total Oil and Gas & 8.2 & 8.1 & 8.0 \\
\hline 2.1 & Enhanced oil and gas & 3.5 & 3.4 & 3.4 \\
\hline 2.2 & Refining, transport and storage & 2.6 & 2.6 & 2.6 \\
\hline 2.3 & Oil shale and tar sands & -1 & - & \\
\hline 2.4 & Other oil and gas & 2.1 & 2.1 & 2.1 \\
\hline 3 & Total Coal & 3.9 & 4.4 & 2.8 \\
\hline 3.1 & Production, preparation and & & & \\
\hline 3.2 & transport & 1.1 & 1.8 & 0.3 \\
\hline 3.3 & Coal combustion & 1.7 & 1.9 & 1.8 \\
\hline 3.4 & $\begin{array}{l}\text { Coal conversion } \\
\text { Other coal }\end{array}$ & 1.1 & 0.8 & 0.8 \\
\hline 4 & Total solar & 11.2 & 11.8 & 15.8 \\
\hline 4.1 & Solar heating and cooling & 1.0 & 0.3 & 0.4 \\
\hline 4.2 & Photo-electric & 10.1 & 11.4 & 15.4 \\
\hline 4.3 & Solar thermal & & 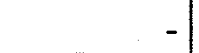 & \\
\hline 5 & Total wind & 6.3 & 5.1 & 6.6 \\
\hline 6 & Total ocean & - & 4 & \\
\hline 7 & Total biomass & 3.7 & 4.7 & 4.8 \\
\hline 8 & Total geothermal energy & 0.05 & 0.05 & 0.1 \\
\hline 9 & Total hydro & 0.05 & & \\
\hline 10 & Total nuclear fission & 12.6 & 11.4 & 10.9 \\
\hline 10.0 & General & 1.5 & 1.6 & 1.5 \\
\hline 10.1 & LWR & 6.0 & 4.6 & 3.3 \\
\hline 10.2 & Other converter reactors & 0.6 & 0.8 & 0.8 \\
\hline 10.3 & Fuel cycle & 3.5 & 2.6 & 1.9 \\
\hline 10.4 & Nuclear supporting technology & 1.0 & 2.0 & 3.4 \\
\hline 11 & Fusion & 6.5 & 5.5 & 7.1 \\
\hline 12 & $\begin{array}{l}\text { Total power and storage } \\
\text { Technologies }\end{array}$ & 14.2 & 15.2 & 14.4 \\
\hline 12.1 & Electric power conversion & 10.7 & 10.8 & 10.4 \\
\hline 12.2 & Transportation, distribution and & 3.3 & 4.2 & 3.8 \\
\hline 12.3 & $\begin{array}{l}\text { storage } \\
\text { Energy storage }\end{array}$ & 0.2 & 0.2 & 0.2 \\
\hline 13 & $\begin{array}{l}\begin{array}{l}\text { Total Other Crosscutting Techn. or } \\
\text { Research }\end{array} \\
\end{array}$ & 16.6 & 12.9 & 14.7 \\
\hline 13.1 & Energy systems analysis & 6.4 & 7.0 & 7.1 \\
\hline 13.2 & Others & 10.1 & 12.9 & 7.6 \\
\hline & Total & 130.7 & 129.8 & $\overline{137.4}$ \\
\hline
\end{tabular}




\section{ENERGY R\&D PROGRAM DESCRIPTIONS}

This final section of the report presents program level descriptions of Dutch public sector energy R\&D programs. In this section, only the budgets of specific identifiable energy R\&D programs will be discussed, i.e., it is likely that some university funded energy $R \& D$ that is supported through the "primary flow" subsidy for university-based research is not fully accounted for here. Not all energy R\&D resources in the Netherlands are allocated through specific or thematic programs. Specifically, this section will detail the energy R\&D programs of Novem, the energy R\&D activities of ECN, specific energy-related programs of NWO, and energy research projects supported through the EconomyEcology-Technology (EET) program, which is currently the most important subsidy supporting general R\&D. 43

The changes in Dutch energy $R \& D$ priorities that were formulated in the recent Memorandum on Energy $R \& D$ are not detailed here (although sometimes mentioned) because many of the programs that will implement these new priorities have yet to be developed (Ministry of Economic Affairs, 1998b).

\section{Energy Efficiency R\&D}

Energy conservation accounts for $38 \%$ of all Dutch public energy RD\&D, making it the single largest energy R\&D program area (Struker, April 1998). Energy efficiency R\&R budgets increased $9 \%$ between 1994 and 1997. The main objective of public sector energy efficiency research is to assist in achieving the government's stated objective of reducing energy consumption by $33 \%$ by the year 2020 (Ministry of Economic Affairs, 1995).

\section{Industrial Energy Efficiency}

$\$ 32.7$ million (1996)

The largest part of the energy efficiency RD\&D budget is devoted to industrial energy efficiency research. These programs account for $65 \%$ of all energy conservation RD\&D and approximately $25 \%$ of total government energy RD\&D expenditure (Struker and de Jager, April 1998). Novem has supported industrial energy efficiency research since the first oil crisis in the 1970s. One major industrial energy efficiency program is the Tender on Energy Conservation (TIEB, since 1990) program ( $\$ 7$ million, 1998), which attempts to stimulate the introduction of available innovative energy conservation techniques in industry.

Novem also supports industry-specific and inter-industry energy efficiency research programs $(\$ 16.0$ million, 1998). For example, the program on inter-sectoral new technologies (MINT, 1994-1998) stimulated the development of crosscutting energy conservation technologies, e.g., energy management, process control and electrical engineering, process integration and residual heat, heat transfer, and physical process equipment. This program ended in 1999 and will be continued through the SPIRIT program (1999-2002) (\$42 million). It aims to accelerate the application of industrial "breakthrough"

\footnotetext{
${ }^{43}$ The EET programme was recently initiated by the Ministry of Economic Affairs and is a part of the "Knowledge in Action" program (Ministry of Economic Affairs, 1995). EET has an annual budget of approximately $\$ 20$ million, which supports research in the areas of environmentally friendly product development, transportation technologies, renewable energy, and sustainable industrial production technologies. EET will provide a maximum annual subsidy of $\$ 5$ million per project. The percent of the project's total cost that is subsidized depends on the characteristics of the project (i.e., $62.5 \%$ subsidy for basic research, $40 \%$ for industrial research, and $25 \%$ for precompetitive technology development). Projects are required to be capable of delivering a substantial "breakthrough," must be carried out cooperatively with another entity, must deliver "economic," "ecology," and "technology" benefits and must be focused on developing technologies which could be implemented in the medium (5-10 year) to long term (10-20 year).
} 
technologies in the market. Budget available in 1999 is about $\$ 5$ million. Novem's sector-specific programs support industries, which have first signed a Long Term Agreement, in which they committed themselves to realizing increased energy efficiency. Currently, the government is sponsoring industrial energy efficiency research that is relevant to the following industrial sectors: building materials, ceramics and glass, chemical and oil refinery, light industry, pulp and paper, textiles, basic metals, rubber and plastic processing, and agricultural.

ECN's Energy Efficiency Unit conducts research on optimizing industrial processes in order to reduce raw material use and realize energy efficiency gains. Research is focused on controlling industrial processes and developing breakthrough technologies (e.g., modeling and simulation of the recovery of heat through for example heat pumps, developing new materials for heat exchangers and heat-resistant and corrosive-tolerant membranes, and the development of fuzzy logic for advanced measurement systems. In addition, the unit is developing needed software, advanced material components (ceramic materials and advanced coatings), demonstrations and experimental equipment.

The Technology Foundation (STW) of NWO is running a four-year, \$4 million program entitled "Process Renewal to Create a Cleaner Environment" (1997-2001). The major research focus of this program is the development of multi-functional catalysts and overall processes that would use these catalysts, e.g., intrinsically clean oxidation processes, application of enzymes and catalytic end-of-pipe processes. This research is performed at universities. The Foundation (STW/NWO) is also supporting basic research that would improve the scientific basis for crystallization separation processes (about $\$ 1.2$ million per year) as well as university-based sensor technology development (e.g., chemical, electrical, mechanical, magnetic and radiation sensors).

The EET program is subsidizing three exemplary industrial energy efficiency RD\&D projects: the development of a biological treatment of process water in a paper mill to close the water cycle; the development of an automated sensor and control system for the use of water in a closed horticulture system; and the development of capillary modules of membrane technology to purify process water (removal of organic components and salts) to enable reuse of water in the food \& beverage and chemical industries.

\section{Building Energy Efficiency}

7.5 million US\$ (1996)

In the building sector, the government's program principally emphasizes information dissemination and market introduction activities. R\&D plays a minor role. About $15 \%$ of the government's energy conservation RD\&D effort is devoted to buildings energy efficiency RD\&D in the residential and commercial sectors (Struker and de Jager, April 1998). Buildings energy efficiency research budgets decreased from 1990 to 1995 . However, recently Novem has started new programs in this area (e.g., heat pumps and building energy infrastructure). The Programme on Long-term Research in the Built Environment (LTGO) ( $\$ 2.5$ million, 1998) seeks to bring about the realization of "energy neutral cities" by the year 2010. Energy neutral cities will be brought about by the introduction of energy saving technologies and the deployment of renewable energy technologies. The government is also developing concepts for energy neutral houses. For 1998, the focus within the program is on the development of energy efficient concepts for newly built urban areas and commercial buildings ( $\$ 0.9$ million) and on test-bed experiments ( $\$ 1.5$ million).

Government-funded building energy efficiency research also plays an important role in shaping national energy conservation policy, e.g., helping to set new Energy Performance Standards for appliances. Another aspect of this synergy between building research and environmental policy and standards is found in the Optimal Energy Infrastructures (OEI) project ( $\$ 0.5$ million 1998). This project provides 
advice regarding energy conservation and the implementation of renewable energy technologies in large, new building areas in the Netherlands (so called VINEX locations, a combination of residential housing and new business areas). Additional funds ( $\$ 1$ million 1998) are provided to demonstrate and stimulate the introduction of gas-fueled appliances in houses and commercial buildings (e.g., washing machines, refrigerators, cooling). Novem also has budgeted approximately $\$ 2$ million for 1998 to realize various building energy efficiency policy goals, such as enhancing energy efficiency in new commercial buildings, intensifying municipal policy regarding building energy efficiency, and stimulating energy efficiency in government-owned buildings. 44

Novem also plays a role in attempting to catalyze the introduction of "sustainable buildings" by bringing together the forces of technology push and market pull together. The National Centre for Sustainable Building (DuBo) was established in late 1996 to validate and disseminate relevant information to the private sector on sustainable building practices.

The ECN Renewable Energy Unit also focuses some of its efforts on the practical integration of renewable energy and energy efficiency technologies in the built environment (e.g., optimum insulation levels, correct installation of heat sources, heat recovery from ventilation air, optimum sun-facing position for buildings, solar collectors, energy roofs and energy poles, 45 cogeneration, heat storage, automated lighting). The EET program is also supports Ecobuild, a program to decrease energy use in houses by $50 \%$ with only minimal additional cost and to introduce new technologies that reduce the lifecycle impact of the entire building.

\section{Traffic and Transport Energy Efficiency}

\$6.7 million (1996)

The transport sector is responsible for about $20 \%$ of Dutch energy consumption. The government devotes approximately $13 \%$ of all energy conservation RD\&D to transport-related energy efficiency research in order to help reduce energy consumption, pollution (e.g., $\mathrm{NO}_{\mathrm{X}}$ emissions), and congestion problems associated with this sector (Struker and de Jager, April 1998).

Novem's transportation energy efficiency program covers a wide array of activities: developing technology, improving logistics, and stimulating the adoption of more fuel-efficient cars. The program on Rational Energy Consumption in Traffic and Transport (REV) (\$2.5 million, 1998) aims at developing efficient vehicles (e.g., hybrid drive systems, flywheels, lightweight materials), developing and applying alternative transport fuels, and efficiently using transport vehicles (e.g., efficient transport of goods by improving logistics). The renewed REV program is restricting its focus to transport systems, demand reduction and logistics (i.e., it is less technology oriented). A second program in this area, Quieter ( $\$ 2.5$ million, 1998) which is focused on cleaner and more fuel-efficient traffic and transport in urban areas, is focused on reducing urban environmental problems by developing and deploying more environmentally friendly mass transportation and delivery or fleet vehicles and the necessary infrastructure (i.e., fueling station facilities).

The EET is financing two exemplary transportation projects: the development of an optimized drive by using a continuous variable transmission system in combination with a flywheel to store and reuse brake energy; and the development of lightweight semi-manufactured components for the transport sector by using renewable resources such as natural fibers like hemp.

\footnotetext{
${ }^{44}$ The government has set a goal of increasing the energy efficiency of government-owned buildings by $17 \%$ by 2000 compared to 1989 energy usage patterns.

45 "Energy roofs" combine a heat exchanger, heat pump, and solar collector to augment traditional heating technologies. "Energy poles" are buried to store underground heat and cold for later use by the heat pump.
} 
Heat pumps are an important aspect of Dutch energy efficiency measures because of the continued widespread availability of low-temperature waste heat. Approximately $3 \%$ of all government energy efficiency research is directed towards heat pump R\&D (Struker and de Jager, April 1998). Novem is also funding ( $\$ 1.5$ million 1998) a heat pump program which encourages the application of heat pumps in the residential sector, service/commercial buildings and in industry. The principal impediments to the further introduction of heat pumps in these three sectors are the high prices of heat pump systems and the lack of experience and systems knowledge of vendors and users. Novem is also trying to establish a Covenant for Heat Pumps to bring together suppliers, energy utilities, and the government to facilitate the development of new, improved products and to create a market for these technologies. Both of these activities are focused on the dissemination and market penetration of heat pump technology. Other Novem programs (such as MINT and NECT) deal with more research-oriented aspects of heat pump technology (e.g., the development of new types of chemical heat pumps, hybrid heat pumps, replacement of ozone-depleting working fluids).

\section{Renewable Energy R\&D}

Renewable energy research accounts for $16.5 \%$ of the total government energy RD\&D budget (Struker and de Jager, April 1998). The government is increasing the resources devoted to photovoltaic (PV) and biomass research (e.g., the "Action Programme on Renewable Energy", Ministry of Economic Affairs, 1997). Solar energy currently receives $55 \%$ of all government renewable energy $R \& D$, wind energy accounts for $24 \%$ of renewable energy RD\&D, and biomass accounts for $22 \%$.

\section{Solar energy}

$\$ 11.8$ million (1996)

Novem has research programs that focus on both thermal solar technologies and PV technology, with the clear emphasis being on PV-related research. The $\$ 2.5$ million (1998) National Programme on Thermal Solar Energy (1996-2000) has as its highest priority the deployment of solar domestic hot water (DHW) systems. The government would like to see 400,000 solar DHW systems deployed by the year $2010-\mathbf{a}$ substantial increase from the current 26,000 DHW systems in use. A nation-wide campaign and a Voluntary Agreement (1999-2002), involving (among others) the solar heating industry, energy distribution companies, Holland Solar, and the Dutch Ministry of Economic Affairs, will promote the development and use of commercially competitive solar DHW systems. The program is also providing some support for technical research and development, and stimulating the market deployment of largescale, custom-built systems and the wider use of passive solar energy in new buildings and renovation projects. Some longer-term exploratory research is also supported to integrate thermal solar energy systems with heat pumps and with seasonal energy storage. Most R\&D activities in this field are carried out with international cooperation through the International Energy Agency.

The publicly supported PV research program in the Netherlands covers all different types of PV cell types (amorphous silicon, silicon thin layer cells on ceramics, organic cells, high efficiency "tandem cells"). The PV program also supports R\&D on how to scale up PV manufacturing production and advanced deposition technologies. Recently, Novem launched a second PV research program, Photovoltaic Solar Energy (NOZ-PV 1997-2000) (\$15 million, 1998), to prepare the market and the manufacturing capabilities for the large-scale implementation of PV solar energy in the twenty-first century. The government hopes to improve the price-performance ratio of PV systems by a factor of four by the year 2010 . Half of the cost reduction is expected to come from advances in $R \& D$, half from 
economies of scale once the market is better developed. The government-funded program is also looking at improving and expanding industrial capabilities in the areas of optimizing inverter technology, $\mathrm{AC}$ modules, PV roof tiles and roof-integration techniques. The government has set aside $\$ 8$ million for a "Learning Programme" to increase knowledge about how to implement wide-scale deployment of PV systems and what the impact of wide-scale deployment of this technology would be (e.g., roof integration, exploring ownership issues, effects on the grid, storage requirements). The ECN Renewable Energy Unit focuses on system/infrastructure technologies for both grid-connected and standalone systems. A competitive production technology has been developed for crystalline silicon solar cells.

In 1995, NWO launched the "Solar Cells for the $21^{\text {st }}$ Century" program ( $\$ 4.5$ million over 4 years). This program will focus on amorphous silicon cell research (structure; optical doping a-Si; tandem solar cells, plasma, thermal arc and large-scale deposition, deposition modeling), multi-crystalline silicon PV cells (optical doping, electrical passivation, organo-functional materials, light confinement); and hybrid solar cells (fabrication and optimization, modeling of hetero-junction). Within the EET program four exemplary projects are financed: (1) using Epitaxial Lift Off Technology (ELOT) in developing a (trial) manufacturing process for highly efficient tandem solar cells; (2) the development of a prefab roof profile that integrates the functional requirements of a roof with PV technology in modules which are easy to implement; (3) the development of technologies to guarantee large-scale competitive manufacturing of crystalline silicon solar PV modules; and (4) the development of a greenhouse in the horticultural sector that does not require natural gas for heating but instead minimizes energy requirements and optimizes the use of renewable energy technologies (e.g., solar energy, heat storage).

In 1997, the government and various private sector actors 46 signed a Voluntary Agreement in which they committed themselves to realizing 7.7MW of installed PV capacity by 2000 and 10PJ of solar power by 2020 .

Wind energy

$\$ 5.1$ million (1996)

Dutch government wind energy programs have existed since 1976. Dutch public sector wind energy research, concentrated at ECN and Delft Technical University, focuses on optimizing the aerodynamics, producing fatigue-tolerant rotor blades, reducing the wind turbine manufacturing cost, and validating structural fatigue models and airfoil models. Research is also conducted on: structural dynamics, strength and fatigue research on full-scale turbine blades, electric conversion, reliability analysis and field experiments. Every two years since 1996 these two partners along with Novem formulate a national R\&D plan to increase the synergy between government funded wind research and industrial needs related to wind energy. This industrial input helps to shape specific national priorities for wind energy research (e.g., design rules for the aerodynamics of the rotors, development of new rotor concepts, development of a dynamic model for offshore wind turbines, increased knowledge of the applicability of new materials). Novem has launched the Use of Wind Energy in the Netherlands (TWIN-2) program ( $\$ 5.5$ million, 1998) to increase the installed wind energy capacity. The TWIN-2 program (1996-2000 approximately $\$ 35$ million) was launched because the current installed capacity of only $325 \mathrm{MW}$ (in 1998) is far below the government's target of 1,000 MW by the year to 2000. Specific aims for TWIN-2 include the installation of at least of $100 \mathrm{MW}$ each year and a $30 \%$ improvement in the price/performance over the period 1995-2000. Clearly, the focus in TWIN-2 is not purely R\&D. The program principally focuses on ways to stimulate the market, contribute to the development of sites (including off-shore and semi-off shore), and strengthen societal acceptance of wind energy (e.g., overcome the so-called NIMBY

${ }^{46}$ The Ministry of Economic Affairs; several electricity distribution companies; EnergieNed; Shell Solar Energy (producer of PV systems); producers of inverters, roofing tiles; real estate developers; consultants; municipalities (e.g., new residential areas). 
syndrome). The EET program supports two exemplary wind energy projects: the development of an offshore wind turbine and the development of rotors produced by using natural fibers.

Biomass energy

$\$ 4.7$ million (1996)

The government believes that if it is to meet its objective of having renewable energy contribute $10 \%$ of primary energy by 2020 biomass (both waste products and "clean biomass") must play a major role. Accordingly, R\&D budgets for biomass are increasing (Struker and de Jager, April 1998). In 1996, government support for biomass energy RD\&D accounted for approximately $22 \%$ of all renewable energy RD\&D.

The Dutch government sees negative value waste streams as a niche application that can improve the early adoption of biomass technology in an economically attractive way through the use of waste incinerators and co-combustion (e.g., waste wood and sludge) in coal-fired power stations. Over the longer term, the focus for biomass use must shift to more advanced options such as biomass gasification. Dutch biomass R\&D focuses on the characterization of conversion properties; the pre-treatment systems for conversion of biomass; and the design, modeling, and optimization of different biomass or waste-toenergy conversion systems (combustion, gasification, pyrolysis, fermentation). Novem implements the Energy from Waste and Biomass ( $\$ 4.5$ million, 1998) program, which concentrates on ensuring the sufficient availability of biomass fuels, e.g., the production of biomass, the use of waste streams (e.g., organic waste, waste from agricultural production, wood and sludges), and the importation of biomass. This program also funds research on pre-treatment systems; conversion technologies such as combustion of biomass, co-combustion in coal fired power plants, CHP, gasification of biomass, pyrolysis, liquefaction or carbonization, landfill gas, fermentation, and improved conversion in waste incinerators; and market conditioning and efforts to increase the societal acceptance of biomass energy. The development of conversion technologies occurs together with energy utility companies and the waste industry. Production of biomass in the Netherlands is studied in cooperation with the agricultural sector (e.g., the semi-public research institute DLO). Novem is currently implementing the GAVE program, which will stimulate the development of gaseous and liquid bio-fuels.

The government's programs to reduce $\mathrm{CO}_{2}$ emissions and its investment program to stimulate innovative cogeneration-projects (NEWS) also fund many biomass-related projects. For example, Nedalco, a producer of ethanol, is planning to build a plant to produce bio-ethanol from melasse, a byproduct of sugar production. Biomass research at ECN's Fuels, Conversion and Environment Unit covers system comparisons of different conversion routes, modeling activities, fuel conditioning and fuel gas and flue gas cleaning, lab and bench scale measurements, and characterization of different biomass/organic waste streams and ash agglomerates in a database (using e.g., the fluidized bed gasifier BIVKIN). EET funds a program that is attempting to produce "crude oil" by converting wet wood shavings under high pressure and high temperature (known as the HTU Process).

Other renewable energy sources $<0.5$ million USS (1996)

The Dutch government's support of other renewable energy R\&D such as ocean energy, geothermal energy and hydropower accounts for less than $0.5 \%$ of the total government renewable energy RD\&D budget. Besides some paper system studies, the government is supporting some research on the storage of hydrogen in metals, and the development of membranes to separate hydrogen. At present, the government does not fund any research directed at the large-scale application of hydrogen in the energy system. The government funds a small program "Market Implementation of Energy Storage in Aquifers" (\$ 0.5 million, 1998) that is exploring the viability of the market introduction of thermal energy storage in aquifers for use in commercial buildings and in industrial processes (e.g., replacing cooling with ground 
water). The EET program is financing the development of a prototype for the "Archimedes Wave Swing," a system that will generate electricity from the undulation of the sea.

\section{Fossil Energy}

Coal R\&D

$\$ 4.4$ million (1996)

The Dutch government has continuously reduced its support for clean coal technologies over the course of the last ten years. Clean coal technology research (e.g., combustion, conversion and flue gas cleanup) accounts for approximately $3.5 \%$ of the government's total energy RD\&D budget (Struker and de Jager, April 1998). The focus of Dutch coal-related research has always been on ways to improve the efficiency of the conversion process. In the area of coal gasification, ECN's Fuel, Conversion and Environment Unit supports research in the following areas: coal conversion and mineral matter behavior in modern pulverized coal fired boilers, combined $\mathrm{SO}_{\mathrm{X}} / \mathrm{NO}_{\mathrm{X}}$ removal from flue gases, and the further development of integrated gasification combined cycle technology (e.g., mineral matter behavior in both the gasifier and in downstream equipment, co-gasification of coal, biomass and high temperature gas cleaning). A $250 \mathrm{MW}_{\mathrm{e}}$ coal gasification demonstration unit in Buggenum was recently competed. Novem is currently closing out most of its coal-related research. It will still support some research related to coal gasification, co-combustion of coal (with biomass), $\mathrm{CO}_{2}$ capture and sequestration, and underground coal gasification (a European Union project with field trails underway in Spain), and coal bed methane recovery (using $\mathrm{CO}_{2}$, with a net sequestration of $\mathrm{CO}_{2}$ ). There is growing interest in this coalbed methane $/ \mathrm{CO}_{2}$ storage program. Since $1990, \mathrm{R} \& \mathrm{D}$ for $\mathrm{CO}_{2}$ capture and sequestration has become increasingly interesting to the Dutch government. In particular, the availability of depleted natural gas fields and research related to advanced clean coal conversion technologies stimulated the government's attention. The Ministry of Housing, Spatial Planning, and Environment and Novem have funded research on $\mathrm{CO}_{2}$ capture and sequestration focused on the potential for carbon dioxide capture in the Netherlands. Currently, both TNO and $\mathrm{ECN}$ are involved in developing $\mathrm{CO}_{2}$ sequestration technologies. TNO is developing gas absorption membranes for $\mathrm{CO}_{2}$ capture, and $\mathrm{ECN}$ is supporting ceramic membranes for $\mathrm{CO}_{2}$ capture, which ECN believes is preferable way of separating $\mathrm{CO}_{2}$. Currently, there is no specific, readily identifiable budget for $\mathrm{CO}_{2}$ capture and sequestration.

\section{Natural Gas and Oil R\&D}

$\$ 8.1$ million (1996)

Natural gas and oil are important raw materials in the Netherlands -- natural gas mainly as raw material for the energy supply system (both electricity and heat), oil as a resource for the (chemical) industrial activity. The Dutch government has funded little or no research on exploration, production and distribution of oil and natural gas in the Netherlands. This area of research has traditionally been adequately supported by the large Netherlands-based oil and gas companies. Research related to oil and gas recovery, refining and transport receive $6 \%$ of governmental energy RD\&D (Struker and de Jager, April 1998). There is some government support for natural gas use through the industrial specific programs (see above under Energy Efficiency). Dutch universities (Delft Technical University, VUAmsterdam and Utrecht University) do conduct research in the area of geology and geophysics supported by the government and industry. Most of this academic research is directly in line with the R\&D needs of the industry: processing of seismological data, characterization of rock behavior, ground mechanics, complex fluid flows, modeling activities, and reservoir management. There is well-embedded (e.g., joint PhD's) cooperation with key companies like Shell, Amoco, Schlumberger and the NAM. The presence of large natural gas deposits in the Netherlands has also stimulated the development of a research infrastructure and advanced physical infrastructure and industrial activity in the area of natural gas. The 
research activities of Gasunie Research and GasTEC cover exploration, distribution and end use of natural gas. These institutes also cooperate with the public research institutes (e.g., combustion research).

Electric Power and Storage

$\$ 15.2$ million (1996)

Electric power and storage technologies account for $12 \%$ of the government's energy RD\&D budget with approximately $70 \%$ of these resources being devoted to research on combined heat and power and fuel cells. The remainder is devoted to research on improving electricity transmission and distribution. The government devotes relatively little funding to energy storage, e.g., electrochemical storage and thermal storage (Struker and de Jager, April 1998). Novem supports research on new conversion technologies, primarily carried out through the New Energy Conversion Technologies (NECT) program ( $\$ 3$ million, 1998). NECT's research activities are focused on increasing the conversion efficiency of decentralized (gaseous) fuels (e.g., natural gas, biogas, low-caloric gases, hydrogen) to produce heat (or cold) and/or power. The program supports research on advanced combustion (e.g., ceramic burners, vortex burners, catalytic burners), innovative combinations (e.g., fuel cells and gas turbines, or adsorption cooling and gas turbines), the development of micro-CHP (using the Free Piston Stirling Engine), small gas turbine technology, and new heat pump technologies (e.g., hybrid and adsorption heat pumps).

STW/NWO subsidizes university research projects in the area of "Clean and Efficient Combustion" (about $\$ 4$ million per year). Funded projects cover e.g., deflagration in flowing and burning gas mixtures, modeling activities regarding turbulent flames, combustion and gasification processes of pulverized coal, laser diagnostics of the combustion process in diesel engines, and development and application of new simulation and laser measurement technologies for combustion processes.

The government has supported $R \& D$ for fuel cells since 1986. In 1990, the Dutch Fuel Cell Corporation (BCN BV) was established, through which ECN, Stork N.V., and the Royal Scheldegroep B.V. cooperate in developing and commercializing molten carbonate fuel cell (MCFC). Government funding for this fuel cell program has been quite substantial, but in recent years has been declining as this technology gets closer to the marketplace. Novem's current fuel cell program (1996-2000) (\$3.5 million, 1998) is focused on stimulating through research, development and demonstrations the wider application of MCFC, solid oxide fuel cells (SOFC), and solid polymer fuel cell (SPFC). Within this program, ECN is supporting the development of a second generation MCFC that incorporates direct internal reforming so that $\mathrm{CH}_{4}$ can be supplied directly to the fuel cell. Research is also focused on extending the lifespan of the MCFCs by developing alternative electrolytes. The SOFC program is carried out collaboratively between the Technical University of Delft and European Union partners and is directed towards the development of ceramic components (membrane electrode assembles, MEA's), required to develop micro- and mini-cogeneration systems. Other SOFC research activities are focused on methanol fueled application in transport. ECN is developing a methanol-reformer for SPFC application in hybrid vehicles.

The ECN's Fuels, Conversion and the Environment Unit concentrates its attention on developing efficient and environmentally acceptable gas conversion technologies (also coal conversion technologies).

Applied catalysis (essential for, e.g., fuel processing for various types of fuel cells, natural gas combustors, coal gas cleaning, and off-gas cleaning) and advanced materials and ceramic technology (e.g., structural catalysts, ceramic membranes, absorbents for gas cleaning and ceramic burners) are main areas of attention. In the area of advanced gas technology, a micro-cogeneration unit $(1 \mathrm{~kW})$ is being developed on the basis of free piston Stirling technology combined with condensing boiler technology. The government is also sponsoring modeling activities (ASPEN+) to evaluate the technical, economic, and environmental aspects of conversion technologies such as coal and biomass integrated gasifier combined cycle systems; high temperature fuel gas cleanup systems; gas turbine combined cycles; natural 
gas fuelled CHP plants; coal and biomass-derived gas-fueled fuel cell systems (MCFC, SOFC); fuel cells for transportation (PMFC); $\mathrm{CO}_{2}$ removal and disposal/utilization; $\mathrm{H}_{2}$ production from fossil fuels; ceramic membrane applications; ceramic foam and catalytic burner applications; and pyrolysis of mixed plastics.

\section{Nuclear (Fission \& Fusion) R\&D}

$\$ 17.0$ million (1996)

In 1996, approximately 4\% of the government's energy RD\&D budget was devoted to fusion research and approximately $9 \%$ went to support fission research. Nuclear energy R\&D institutes receive their funding directly from the Ministry of Economic Affairs, i.e., it is not channeled through an intermediary like Novem. The Netherlands fusion research activities are mainly performed at NWO's FOM-institute for Plasma Physics (Rijnhuizen). These fusion research activities are integrated with the European Union's fusion program, coordinated by EURATOM. The research is focused on low-activating construction materials, plasma physics, and heat transport in plasmas at high temperatures. Fission energy R\&D is performed by the ECN's Nuclear Energy Unit, Delft Technical University, and KEMA. The focus of this research is on reactor safety and new safer reactor technologies such as HTR / INCOGEN, reactor materials, waste disposal (underground storage in salt layers), probabilistic safety assessments, reliability analysis, non-proliferation (e.g., recycling of the actinides) and decommissioning. In 1997, ECN and KEMA merged their expertise and experience (radiation technology, health physics, energy technology, engineering, and licensing assistance) to form the Nuclear Research \& Consultancy Group (NRG).

\section{Other Energy-Related R\&D Programs}

VROM/NWO National Research Programme on Global Air Pollution and Climate Change In 1995, the Dutch government launched the second phase of the National Research Programme on Global Air Pollution and Climate Change ( $\$ 27.5$ million, 1995-2001). This program supports research currently carried out at more than 30 Dutch universities and research institutes focused directly or indirectly on climate change. This program supports research in four broad theme areas: understanding the climate system and its component parts (theme 1), the effect of climate change on natural and social systems (theme 2), societal causes and solutions for climate change (theme 3 ), and integrated assessment modeling and outreach efforts (theme 4 ). The activities supported by this program are undoubtedly broader than energy R\&D. Sub-themes covered are land use; energy and materials; mobility and transport; population development, lifestyles, and patterns of consumption; perceptions, attitudes, and societal support; and structures, institutions and instruments.

\section{NWO/Novem program to Stimulate University Energy R\&D}

By order of the Ministry of Economic Affairs and the Ministry of Education, Culture, and Sciences, Novem and NWO are developing a program for stimulating university-based energy R\&D (\$6 million in total). The principal focus of this research is to have the universities carry out interdisciplinary research to explore the social/technological factors that would influence the deployment of renewable energy systems aspects. It is also hoped that this program would bring more coherence to university-based energy $R \& D$ and strengthen interactions between basic and applied energy $R \& D$ programs. 
In addition, STW/NWO is initiating a Programme on Renewable and Energy Efficient Energy Sources that will support university-based energy research in the areas of: PV solar energy, heat pumps, efficient coal combustion, and high-temperature superconductivity.

\section{Top Research Schools}

Two of the Netherlands' so-called Top Research Schools carry out research related to energy R\&D. Top Research Schools are selected by the government based upon their demonstrated expertise in a given area and are awarded grants totaling $\$ 1.5$ to 5 million a year over a maximum ten-year period. The Research School "Catalysis Controlled by Chemical Design" (a collaborative effort among 7 universities) focuses on developing tailor-made catalysts. The Research School "Materials Science Centre" (based at the University of Groningen) conducts research related to characterizing the structure and properties of advanced materials such as metals, ceramics and polymers. 
Appendix 1: Organization of Programming and Financing of Public Energy R\&D

Figure 1: Organization of Public Energy RD\&D: Financing

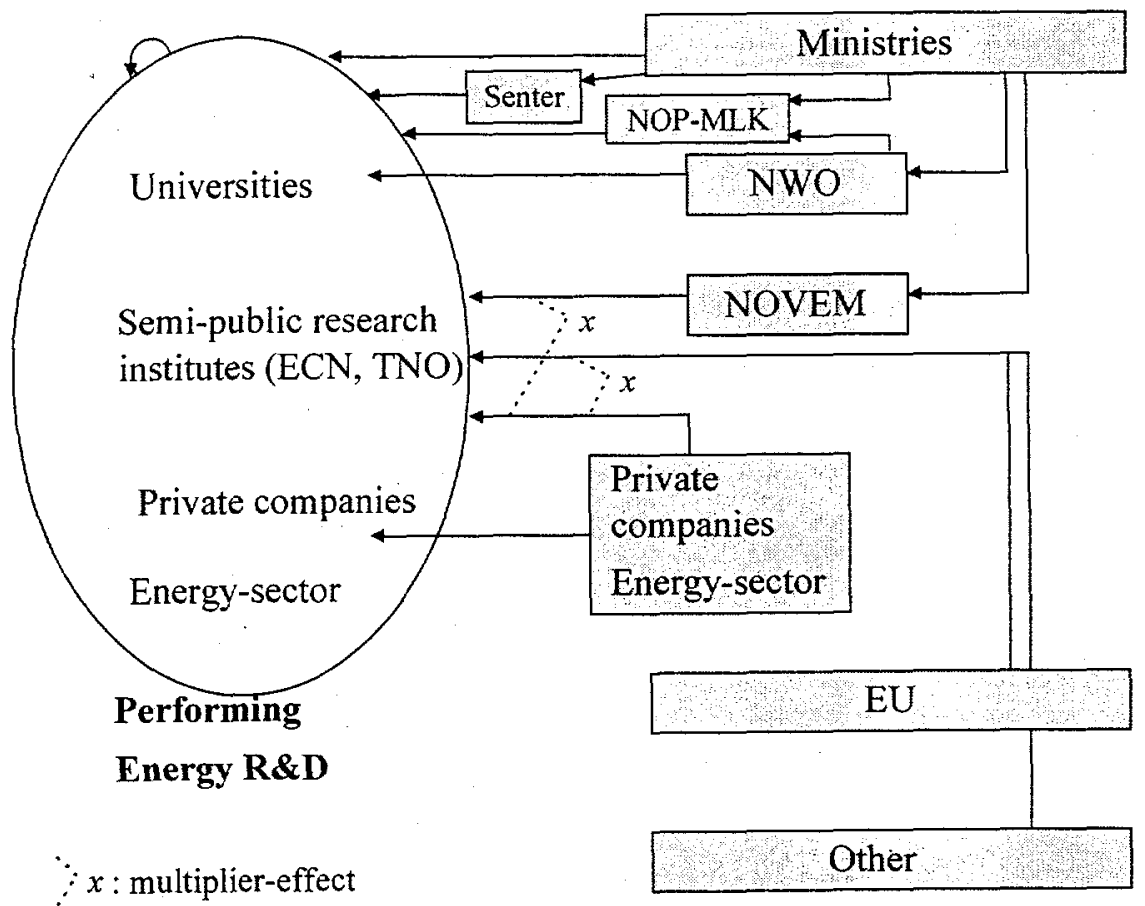

Financing energy R\&D 
Figure 2: Organization of Public Energy RD\&D: Programming

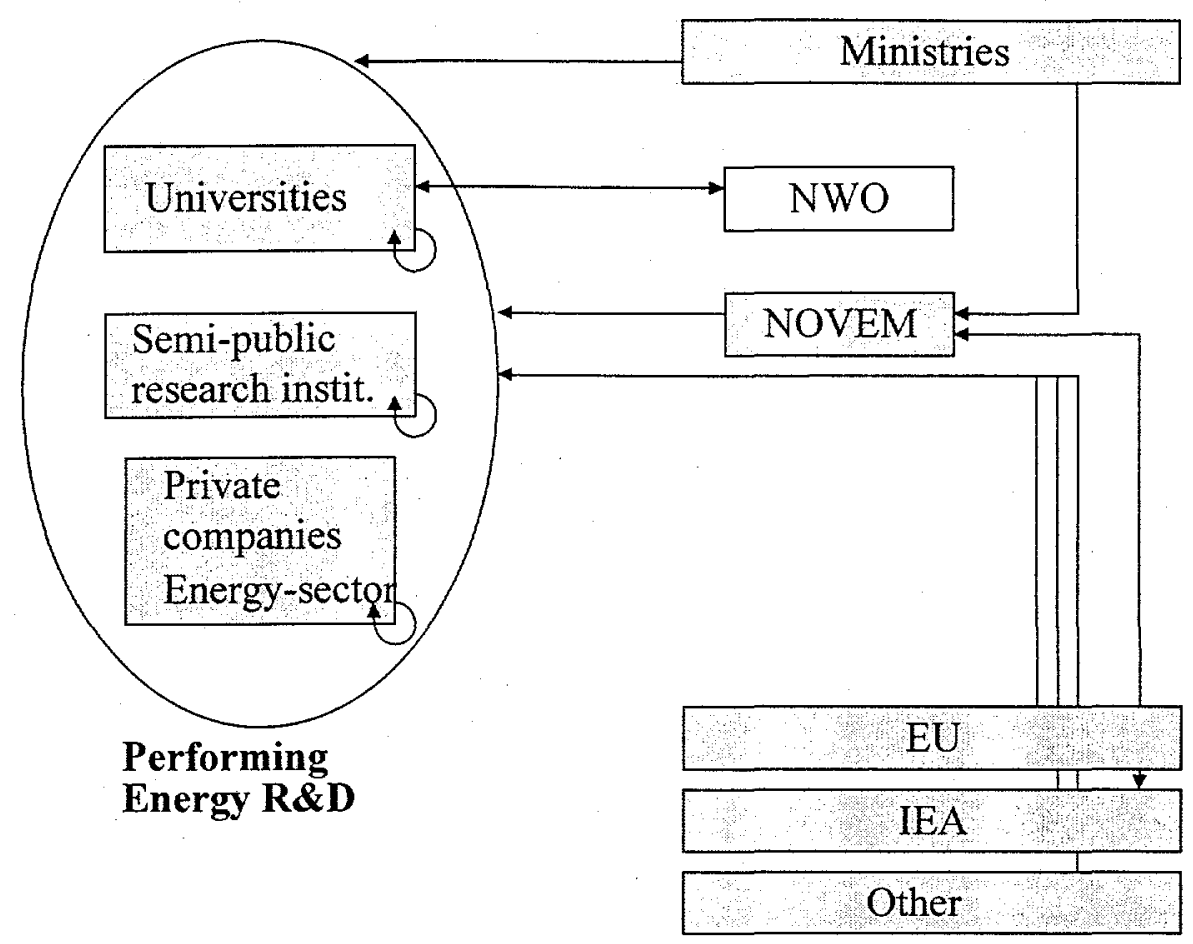

Some of NWO's research is not programmed actively according certain areas. The Technology Foundation of NWO (STW) is running an Open Technology Programme, in which university researchers can submit proposals. STW is trying to pool projects to create synergy among them.

Source: (Strategic Foresight Committee (OCV), February 1996) 


\section{Appendix 2: Detailed Flow of Public Energy R\&D Funds 1996}

Figure 1 gives an overview of the 1996 governmental support towards energy RD\&D, including financiers of energy research, the distribution of Dutch public supported energy RD\&D by major technology area and the performers of R\&D.

Figure 1: Governmental Support for Energy RD\&D: Financing, Technology Areas and Performance (1996)
Funding
Financing stream
IEA classification

Performers
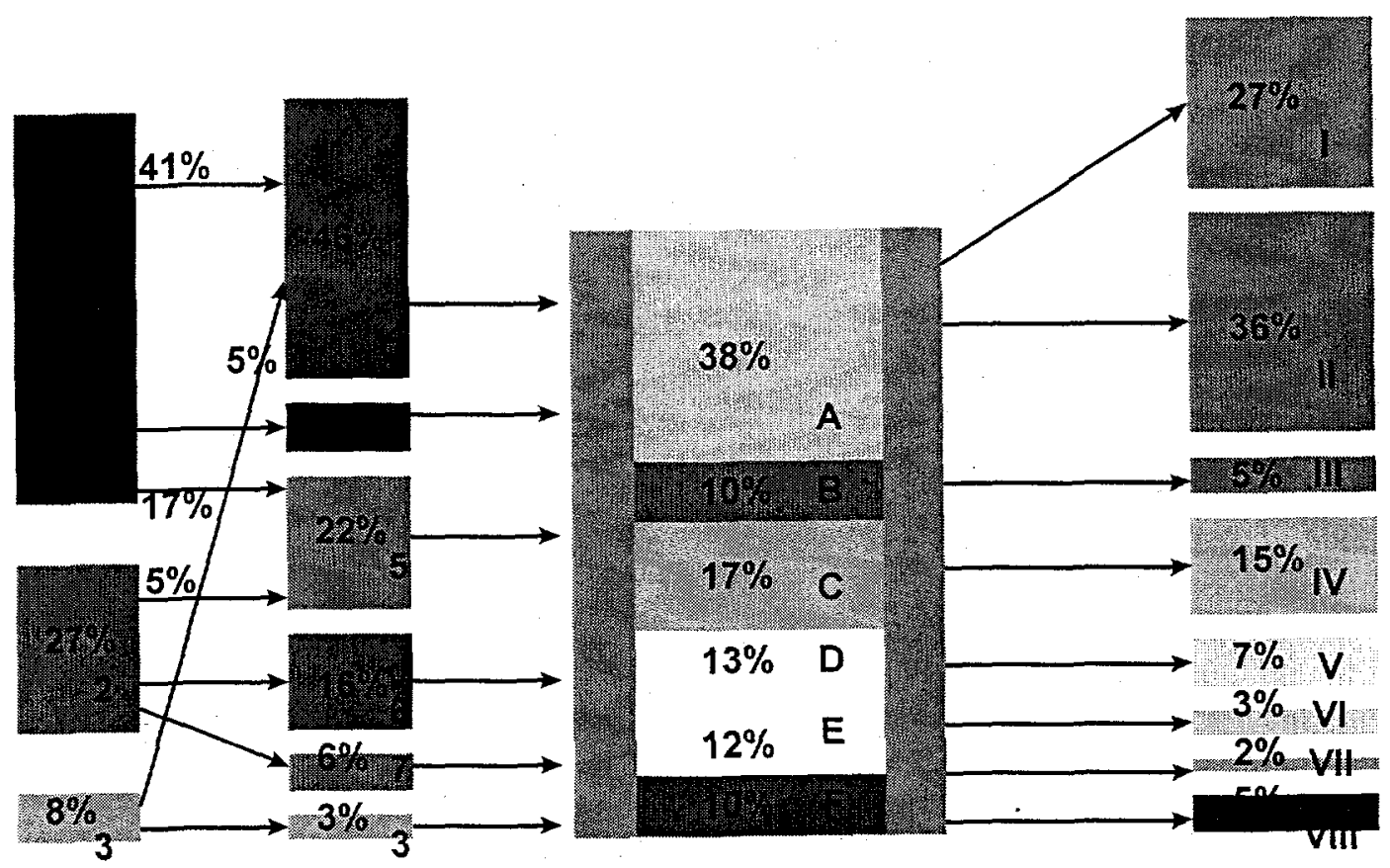

$1=$ Ministry of Economic Affairs

$\mathrm{I}=$ Universities

$2=$ Ministry of Education, Culture, \& Sciences

$3=$ Other Ministries

$4=$ Novem

$5=\mathrm{ECN}$, TNO and FOM

$6=$ Primary flow universities

$7=$ Second flow universities (through NWO)

$\mathrm{II}=\mathrm{ECN}$, TNO and FOM

III = Engineering companies, consultancies

IV $=$ Industry $(<500 \mathrm{fte})$

$\mathrm{V}=$ Industry $(>500 \mathrm{fte})$

$\mathrm{VI}=($ Energy $)$ utility companies

$\mathrm{VII}=$ Provincial and municipal authorities

VIII $=$ Other

\section{Energy R\&D Technology Areas}

A-Conservation

$\mathrm{B}$ - Fossil Fuels

C - Renewable Energy

D - Nuclear Fission and Fusion

E - Power and Storage Technologies

F - Other Crosscutting Tech. or Research

Source: (Struker and de Jager, April 1998) 


\section{Acronyms}

AER
CBS
DLO
ECN
EET Programme
GTI
IEA
NWO
Novem BV
OCV
OCV/VCE
PEO
STW
TNO

\section{General Energy Council}

Netherlands Central Bureau of Statistics

Netherlands Organization for Agricultural Research

Netherlands Energy Research Foundation

Economy-Ecology-Technology Programme

Large Technological Institutes (among others, ECN)

International Energy Agency

Netherlands Organization of Scientific Research

Netherlands Agency for Energy and the Environment

Strategic Foresight Committee

Strategic Foresight Committee / Foresight Committee on Energy

Project Agency on Energy Research (predecessor of Novem)

Technology Foundation (an institute of NWO)

Netherlands Organization for Applied Scientific Research 


\section{Bibliography}

Algemene Energie Raad (AER) (July 1996), Energie-onderzoek in Nederland (Energy Research in the Netherlands), The Hague, The Netherlands.

Arthur D. Little and PA Consultancy (June 1997), Matching Demand and Supply of Energy-related R\&D in The Netherlands, in order of the Ministry of Economic Affairs and the Ministry of Education, Culture, and Sciences, The Hague, The Netherlands.

Centraal Bureau voor de Statistiek (CBS) (October 1996), Kennis en Economie 1996 (Knowledge and Economy 1996), Voorburg/Heerlen, Netherlands Central Bureau of Statistics, The Netherlands.

Centraal Bureau voor de Statistiek (CBS) (September 1997), Kennis en Economie 1997 (Knowledge and Economy 1997), Voorburg/Heerlen, Netherlands Central Bureau of Statistics, The Netherlands.

Centraal Bureau voor de Statistiek (CBS) (1996), De Nederlandse Energiehuishouding: Jaarcijfers 1996 (Energy Supply in the Netherlands: Annual Figures), Voorburg, The Netherlands.

Centraal Bureau voor de Statistiek (CBS) (1997), Milieustatistieken voor Nederland 1996 (Environmental Statistics 1996), Voorburg / Heerlen, Netherlands Central Bureau of Statistics, The Netherlands.

Centraal Bureau voor de Statistiek (CBS) (1998), Statistisch Jaarboek 1998 (Statistical Yearbook 1998), Voorburg/Heerlen, Netherlands Central Bureau of Statistics, The Netherlands.

Centraal Bureau voor de Statistiek (CBS) (yearly report, until 1993), Speur- en Ontwikkelingswerk in Nederland (Research and Development in The Netherlands), Voorburg / Heerlen, Netherlands Central Bureau of Statistics, The Netherlands.

Ministry of Economic Affairs (1990), Nota Energiebesparing - Beleidsplan energiebesparing en stromingsbronnen (Memorandum on Energy Conservation - Policy Plan for Energy Saving and renewable Energy), The Hague, The Netherlands.

Ministry of Economic Affairs (1993), Vervolgnota Energiebesparing (Continued Memorandum on Energy Conservation, The Hague, The Netherlands.

Ministry of Economic Affairs (1995), Derde Energienota (Third White Paper on Energy), The Hague, The Netherlands.

Ministry of Economic Affairs (April 1996), Current lines - towards an electricity market. The framework for a new Electricity Act in The Netherlands, The Hague, The Netherlands.

Ministry of Economic Affairs (March 1997), Duurzame Energie in Opmars - Actie programma 19972001 (Action Plan for Renewable Energy - 1997-2001), The Hague, The Netherlands.

Ministry of Economic Affairs (April 1998a), Energiebeparingsnota (Memorandum on Energy Conservation), The Hague, The Netherlands. 
Ministry of Economic Affairs (April 1998b), Energie Onderzoek in Nederland - Organisatie en Prioriteiten, (Energy Research in the Netherlands - Organization and Priorities), The Hague, The Netherlands.

Ministry of Economic Affairs, Ministry of Education, Culture, and Sciences, Ministry of Agiculture, Nature Management and Fisheries (1995), Kennis in Beweging (Knowledge in Action), The Hague, The Netherlands.

Ministry of Education, Culture, and Sciences (1988), Wetenschapsbudget 1988 (Science Budget 1988), Zoetermeer, The Netherlands.

Ministry of Education, Culture, and Sciences (1997), Wetenschapsbudget 1997 (Science Budget 1991), Zoetermeer, The Netherlands.

Ministry of Education, Culture, and Sciences, (yearly report), Wetenschapsbudget (Science Budget), Zoetermeer, The Netherlands.

Novem B.V. (yearly report), Annual Report, Utrecht, The Netherlands.

Overlegcommissie Verkenningen (OCV) (June 1996), Een vitaal kennissysteem - Nederlands onderzoek in toekomstig perspectief (A Vital Knowledge System - Dutch Research with a View to the Future), Amsterdam, The Netherlands.

Overlegcommissie Verkenningen (OCV)/ Verkenningscommsie Energieonderzoek (VCE) (February 1996), Zoektocht naar richting in een doolhof (Search in a Labyrinth), Amsterdam, The Netherlands.

RAND Europe and Coopers and Lybrand (1998), Technology Radar: Main Report and Executive Summary, in order of the Ministry of Economic Affairs, Delft, The Netherlands.

Senter (October 1997), Energie Technologie-projecten door Bedrijven - Analyse van de S\&O database van Nederland 1994, 1995, 1996 (Energy Technology Projects in the Netherlands - Analysis of the R\&D Database 1994, 1995, 1996), Zwolle, The Netherlands.

Stichting Projectbeheerbureau Energieonderzoek (PEO) (1987). Annual Report 1986, Utrecht, The Netherlands.

Struker, A., D. de Jager (April 1998), Survey of Publicly Financed Energy Research in The Netherlands - 1995, 1996, 1997 (estimates), Ecofys Consultancy, Utrecht, The Netherlands.

Tijssen, R.J.W., Th. N. van Leeuwen, B. Verspagen, H. Hollanders (1998), Wetenschaps - en Technologie- Indicatoren 1998 (Science and Technology Indicators 1998), Leiden / Maastricht, Centrum voor Wetenschaps- en Technologie Studies (CWTS), Rijksuniversiteit Leiden / Maastricht Economic Research Institute on Innovation and Technology (MERIT), Universiteit Maastricht, The Netherlands.

Vereniging van Nederlandse Universiteiten (VSNU) (December 1997), KUOZ - Kengetallen Universitair Onderzoek (Figures on University Research), Utrecht, The Netherlands. 
Wees, M.T. van, A.J.M. van Wijk (September 1995), Long-term Prospects of Energy technologies - the SYRENE Programme summarised, Utrecht University, Department of Science, Technology and Society, Utrecht, The Netherlands.

Weijen, M.P.C. (1994), Op weg naar een nieuwe strategie voor het energie-onderzoek (Developing a New Strategy for Energy Research in The Netherlands), Delft University Clean Technology Institute (Interduct), Delft Technical University, Delft, The Netherlands. 